\title{
Roro shipping vs. trucking: revisiting the impact of low-sulphur marine fuel use on cost competitiveness of routing options in north Europe
}

\author{
Theo Notteboom ${ }^{1,2,3}$
}

Accepted: 9 November 2020 / Published online: 30 November 2020

C) World Maritime University 2020

\begin{abstract}
Academic studies and policy documents have elaborated on the $0.1 \%$ sulphur cap in roro shipping and its potential impact on vessel operating costs, the competitiveness of roro shipping compared to other transport modes and the risks for triggering a 'modal back shift' from sea to road. This study revisits the paper 'The impact of low sulphur fuel requirements in shipping on the competitiveness of roro shipping in Northern Europe' published in this journal as reported by Notteboom (WMU J Marit Aff 10(1), 63-95) by applying a cost model to measure route competitiveness in north Europe in October 2018 and May 2020. We find that the use of low sulphur fuel has only a moderate impact on the cost competitiveness of shortsea routes. Only in a few cases do we see the cost balance in modal competition tilting towards the 'truck only' option. Compared to the findings by Notteboom (WMU J Marit Aff 10(1), 63-95), the compulsory transition to low sulphur emission solutions so far had far less significant impacts on the cost competitiveness of shortsea-dependent routing options. The smaller differences in cost competitiveness compared to Notteboom (WMU J Marit Aff 10(1), 63-95) are partly explained by smaller observed price gaps between HFO and low sulphur fuels and higher road charge costs for trucking. We further demonstrate that lower vessel utilization degrees can seriously affect the cost competitiveness of routing alternatives involving long and shorter roro sections and increase the risk of a modal back shift from sea to road. Contrary to most earlier studies, the combination of many routes and different periods of observation allows to test the robustness of the outcomes taking into account these spatial and temporal dimensions.
\end{abstract}

Keywords Roro shipping $\cdot$ Fuel costs $\cdot$ Modal competition $\cdot$ Baltic $\cdot$ Sulphur $\cdot$ IMO

Theo Notteboom

theo.notteboom@ugent.be

Extended author information available on the last page of the article 


\section{Introduction}

Ship emissions currently account for a considerable share of global greenhouse gas emissions. Maritime shipping is responsible for $4 \%$ of the European $\mathrm{CO}_{2}$ emissions in 2013 (European Commission 2013). The past decades brought an impressive series of regulatory initiatives at the global, supranational and national level aimed at lowering ship emissions. The International Maritime Organisation (IMO) plays a pivotal role in the regulatory field. Just like any other shipping segment, roro shipping is confronted with stronger environmental considerations and stricter regulatory frameworks on ship emissions and energy efficiency such as MARPOL Annex VI (Regulations for the Prevention of Air Pollution from Ships) and MRV (Monitoring, Reporting and Verification), the Sulphur Emission Control Areas (SECAs), the global sulphur cap of $0.5 \%$ (applicable since January 1, 2020) and the Energy Efficiency Design Index (EEDI), mandatory for new ships since 2013. MARPOL Annex VI sets limits on $\mathrm{NO}_{\mathrm{x}}$ and $\mathrm{SO}_{\mathrm{x}}$ emissions from ship exhausts and prohibits deliberate emissions of ozone depleting substances (IMO 2008). Annex VI aims for a reduction in sulphur oxide $\left(\mathrm{SO}_{\mathrm{x}}\right)$ emissions from ships, with the global sulphur cap reduced initially to $3.5 \%$ (from 4.5\%) from January 1, 2012. In October 2016, IMO's Marine Environment Protection Committee reduced the global limit of sulphur content further to $0.5 \%$ (outside SECAs) which is effective since January 1, 2020. The limits applicable in Sulphur Emission Control Areas (SECAs) were reduced from 1.5 to $1 \%$ in 2010 and further to $0.1 \%$, effective from January 1, 2015. There are also provisions for sulphur caps in marine fuels for vessels in ports. Ship operators in north Europe must comply with the $0.1 \%$ sulphur cap as the North Sea, the Baltic Sea and the English Channel are part of the SECAs. A lot of research has been conducted to compare several emission control projects and their economic viability, such as new energy adoption (the use of LNG, hydrogen, etc.), the use of low sulphur bunker fuel, dual fuel ships and the technical retrofitting of ships by installing emission control devices such as scrubbers and selective catalytic reduction (SCR) systems.

Several academic studies and policy documents elaborate on the impact of the implementation of the $0.1 \%$ sulphur cap on roro shipping in north Europe. Academic and nonacademic studies have analysed its potential impact on vessel operating costs (Odgaard et al. 2013), the competitiveness of roro shipping compared to other transport modes (Skema 2010; Notteboom 2011; Morales-Fusco et al. 2012) and the risks for triggering a 'modal back shift' from sea to road (see e.g. Panagakos et al. 2014; Holmgren et al. 2014; Lemper et al. 2009). The 'modal back shift' concerns are fuelled by the observation that shortsea shipping shows a higher price elasticity than traditional shipping as shortsea services on many routes directly compete with road transportation and the barriers for a back shift from shortsea to road transport are small for the customer (European Commission 2015; Morales-Fusco et al. 2018). Next to reviewing all commissioned studies of that time on the possible modal shifts following regulation on low-sulphur marine fuels, Holmgren et al. (2014) do not find concrete evidence supporting a modal shift from sea to road transport, except for some very specific shipping categories and routes. They also confirm the finding of Delhaye et al. (2010) that the impact of the modal back shift will depend on route and sea-leg length, with short distances being affected less. 
Fuel price levels play a role in the competitiveness of roro shipping and modal competition in north Europe. The modal split model of Zis and Psaraftis (2017) applied to seven routes within SECAs showed that the threat of modal shifts was not realized due to the very low fuel prices in 2015, which allowed roro/ropax operators to increase their market shares and profitability. However, Zis and Psaraftis (2018a) warn that major losses of market shares towards land-based alternatives are likely in case fuel prices increase. They propose a series of operational measures for shortsea operators to deal with such a situation and to help them in the transition to a low-sulphur fuel market environment, e.g. reducing the sailing speed, adjusting the sailing frequency, alternating fleet deployment and investing in abatement technologies. Zis and Psaraftis (2018b) presented KPIs to assess and reverse the negative impacts of SECA policies for roro shipping.

To contribute to ongoing discussions on the impact of emission regulation on roro shipping, this paper revisits the paper 'The impact of low sulphur fuel requirements in shipping on the competitiveness of roro shipping in Northern Europe' published in the same journal (Notteboom 2011). Using different fuel price scenarios for heavy fuel oil (HFO) and low sulphur fuel, the cost analysis results of the 2011 study showed that the use of low sulphur fuel was expected to significantly increase modal competition between the roro/truck option and the 'truck only' option in north Europe, particularly on the origin-destination relations with a medium or long shortsea section. The study relied on price scenarios and fuel price differentials between $\mathrm{HFO}$ and low sulphur fuel based on the available knowledge and datasets of that time. In the meantime, the trucking and roro industries have evolved both in terms of technology and overall cost structure, while also fuel price levels and gaps in the shortsea and trucking markets have evolved. Moreover, the road haulage industry is increasingly subjected to road user charging systems which increase the cost per vehicle-kilometre (e.g. LKW-Maut in Germany, kilometre charge in Belgium, etc.). The question thus arises whether the findings presented in Notteboom (2011) still hold in the current market environment. In other words, compared to the findings in Notteboom (2011), did the compulsory transition to low sulphur emission solutions (i.e. the use of low sulphur fuels or the reliance of emission control devices such as scrubbers) so far have less or more impact on the cost competitiveness of shortsea-dependent routing options vis-à-vis 'truck only' routing alternatives? We particularly focus on changes in comparative costs against the background of different fuel cost situations and the use of low sulphur fuel instead of IFO380.

The paper is organised as follows. The next section of the paper focuses on the price evolution and gaps between different marine fuels and diesel for trucks affecting transport operators in north Europe. Section 3 assesses the share of fuel costs in total vessel operating costs and trucking costs for different fuel price levels. Next, the paper presents a comparative cost model in order to analyse the impact of the use of low-sulphur marine fuel on the cost competitiveness of the roro/truck option and the 'truck only' option on thirty origin-destination routes in north Europe. Furthermore, we analyse the impact of the vessel utilization level on the cost model output. Conclusions, limitations and avenues for further research are presented in the last section. 


\section{Recent evolution of fuel prices}

\subsection{Bunker fuels for ships}

Bunker prices constantly fluctuate due to demand/supply dynamics and the cost of crude oil. Heavy fuel oil (HFO) mainly consists of residual refinery streams from the distillation or cracking units in the refineries. IFO380 (intermediate fuel oil) is a mix of $98 \%$ of residual oil and $2 \%$ of distillate oil with max $3.5 \%$ sulphur content. Other bunker fuels than the HFO are the marine diesel oil (MDO) which mainly consists of distillate oil and the marine gas oil (MGO). Existing regulation has pushed a shift to the use of low sulphur fuels or, alternatively, the installation of emission control devices such as scrubbers and selective catalytic reduction (SCR) systems. Very-low sulphur fuel oil (VLSFO) is max 0.5\% sulphur fuel (also known as IMO2020 grade bunkers), while ultra-low sulphur fuel oil (ULSFO) is max $0.1 \%$ sulphur fuel oil for compliance with SECA regulations. MGO also has a low sulphur variant, i.e. LSMGO with max $0.1 \%$ sulphur.

VLSFO blends are rather new; hence, their price reporting in Fig. 1 only starts in the summer of 2019. Specialised press has referred to quality problems with some of these newer blends and the lack of having a defined range of viscosity. The lower the viscosity, the higher the price of the fuel oil, as diluting high viscosity bunker requires more expensive components. In most cases, the viscosity is well defined. For example, IFO380 is a residual oil with viscosity up to 380 Cst. However, the applicable ISO 8217 does not mention anything about the viscosity of new VLSFO. Diluting a high viscosity bunker has become cheaper and easier as a wide variety of low viscosity, and sulphur cheap blend components have become available in recent years.

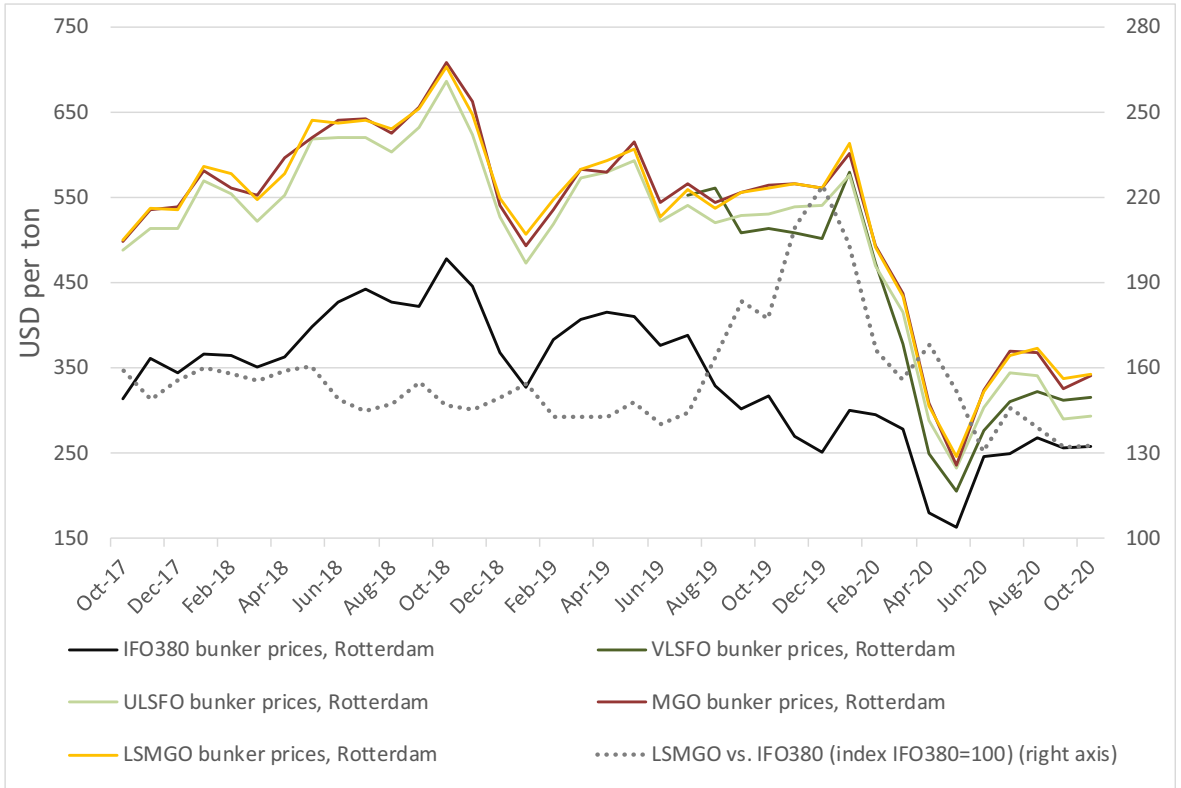

Fig. 1 Spot price evolution of vessel bunker fuels in USD per ton, Oct 2017-Oct 2020. Notes: Rotterdam prices on 6th day of each month. Source: own compilation based on data of ShipandBunker.com 
In the past few years, the price differences between MGO, LSMGO, ULSFO and VLSFO have been very small, and about 30 to $50 \%$ more expensive than IFO380 (dotted line in Fig. 1). Between August 2019 and February 2020, the differential between LSMGO and IFO308 reached a sudden peak caused by speculation and uncertainty preceding the entry into force of the $0.5 \%$ global sulphur cap regulation. The COVID-19 pandemic outbreak in early 2020 led to a significant drop in bunker prices per ton and partly contributed to the narrowing of the price gap between IFO380 and other bunker fuels. Low bunker fuel price levels significantly increase the payback period of scrubber systems (Zis et al. 2016) and thus make the use of low sulphur fuels more attractive.

Notteboom (2011) demonstrated that the price difference between MGO and IFO380 in the period 1990-2008 fluctuated between 30 and $250 \%$ with a long-term average of $93 \%$. The cost of marine distillate fuels used to be about twice what residual fuels costs due to strong demand prior to the financial-economic crisis of 2008-2009 and the cost of the desulphurization process. However, the observed price differences have declined significantly in recent years. The compulsory use of low sulphur fuel of maximum $0.1 \%$ in SECAs since 2015 and the IMO2020 global sulphur cap of $0.5 \%$ have contributed to the narrowing of the price gap between heavy fuel oil and low sulphur alternatives. This seems to indicate that the switch to low sulphur fuels to meet MARPOL Annex VI rules and the IMO2020 sulphur cap turns out to be less costly for the participants in the shipping industry than initially expected. For example, Industrierna (2009) and Notteboom (2011) estimated, based on historical price differences, that the use of MGO $(0.1 \%)$ could well imply a cost increase per ton of bunker fuel of on average 80 to $100 \%$ (long term) compared to IFO 380 , which is $50 \%$ points above the price differential between IFO380 and MGO in recent years (except for the short peak in late 2019, see also Fig. 1). While the fuel price is strongly determined by the oil price and the demand/supply balance for each of the marine fuel grades, forecasting the evolution of the fuel prices and price gaps between bunker fuels remains extremely difficult. Sudden demand shocks caused by the financial-economic crisis of 2008/2009 or the COVID-19 health crisis of 2020 have a far-reaching impact on fuel price levels. Supply strategies of the global refining industry and speculation by traders further add to the uncertainty and volatility in fuel prices.

Roro and ropax operators can in principle deploy a variety of operational and financial strategies to deal with fuel price uncertainty. A ship operator can rely on bunker hedging. However, such practices are not widespread among smaller and medium-sized operators as hedging the bunker price requires a deep understanding of bunker price behaviour, not only the spot price but also the future price as well. Roro and ropax operators can also pass the fuel price volatility risk on to the customer by applying fuel surcharges on top of the base freight rate. These fuel surcharges then partly or fully absorb rising or falling fuel costs.

Figure 2 shows the relationship between sailing distance and fuel consumed in ton per nautical mile $(\mathrm{nm})$ for a sample of 17 traditional shortsea and ropax vessels with an average commercial speed of 18.5 knots. The data were obtained from two major operators in the north European shortsea business with services spread over the SECAs. For confidentiality reasons, the origin-destination relations of the services could not be revealed. The scatter plot reveals that the fuel consumption typically ranges between 0.11 and $0.16 \mathrm{t} / \mathrm{nm}$. The range in fuel consumption of shortsea vessels is attributable to 


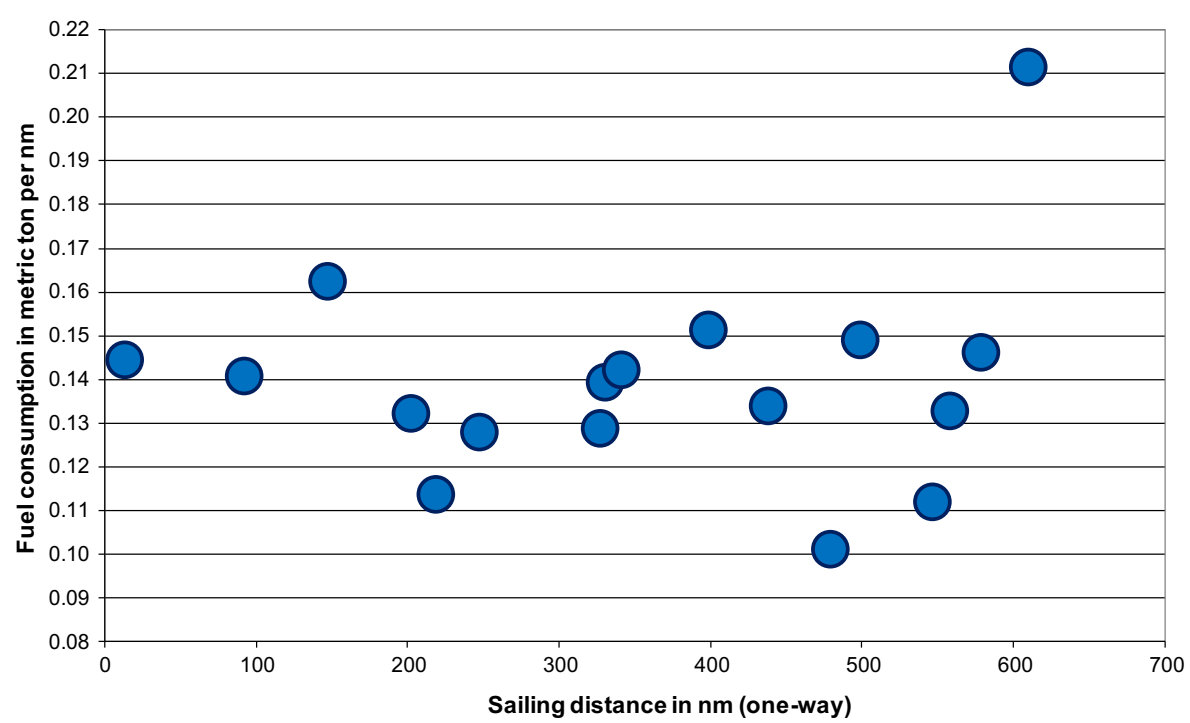

Fig. 2 Fuel consumption in metric ton per nautical mile for a sample of shortsea vessels (speed of $18.5 \mathrm{kn}$ ). Source: based on data provided by ship operators

operational and technical factors such as the unit capacity of the vessel (in dwt and in lane metres), the engine type, vessel age and on-route weather conditions. The sailing distance does not seem to have a large impact on the fuel consumption per nautical mile. The same sample reveals that the fuel consumption for faster shortsea vessels (commercial speeds between 25 and 30 knots which are very rare at present) typically amounts to 0.30 to $0.37 \mathrm{t} / \mathrm{nm}$ or more than double the consumption levels of the more standard vessels.

\subsection{Diesel for trucks}

In $2018,98.3 \%$ of all medium and heavy trucks in the EU ran on diesel, $1 \%$ on petrol and the remainder on LPG, natural gas or other fuels such as hydrogen (ACEA 2019). Diesel prices are heavily affected by national policies in terms of duties and taxes, and the overall strategies in terms of the promotion of intermodal transport and/or the safeguarding of the competitiveness of the national road haulage industry. This explains existing price differences among the 13 north European countries depicted in Fig. 3. These countries have been selected as they are most relevant in the context of empirically assessing route competition in northern Europe. Luxemburg, Lithuania and Poland show the lowest diesel prices, while Sweden, the UK and Belgium typically apply the highest fuel price per litre.

The fuel economy is a key decision variable when fleet managers purchase new or used trucks. Consumption levels of modern heavy-duty trucks (loaded) typically range between 27 and 321 per $100 \mathrm{~km}$ in normal driving conditions. Top of the range trucks aim for an even better fuel economy. For example, the Actros 1845 LS of Mercedes-Benz with the latest Euro VI exhaust technology reached a consumption of 26.51 of diesel per $100 \mathrm{~km}$ under real driving circumstances in the context of the so-called 'fuel duel' tests. An average $420 \mathrm{hp}$ heavy-duty truck will consume roughly two litres of fuel per hour when idling. 


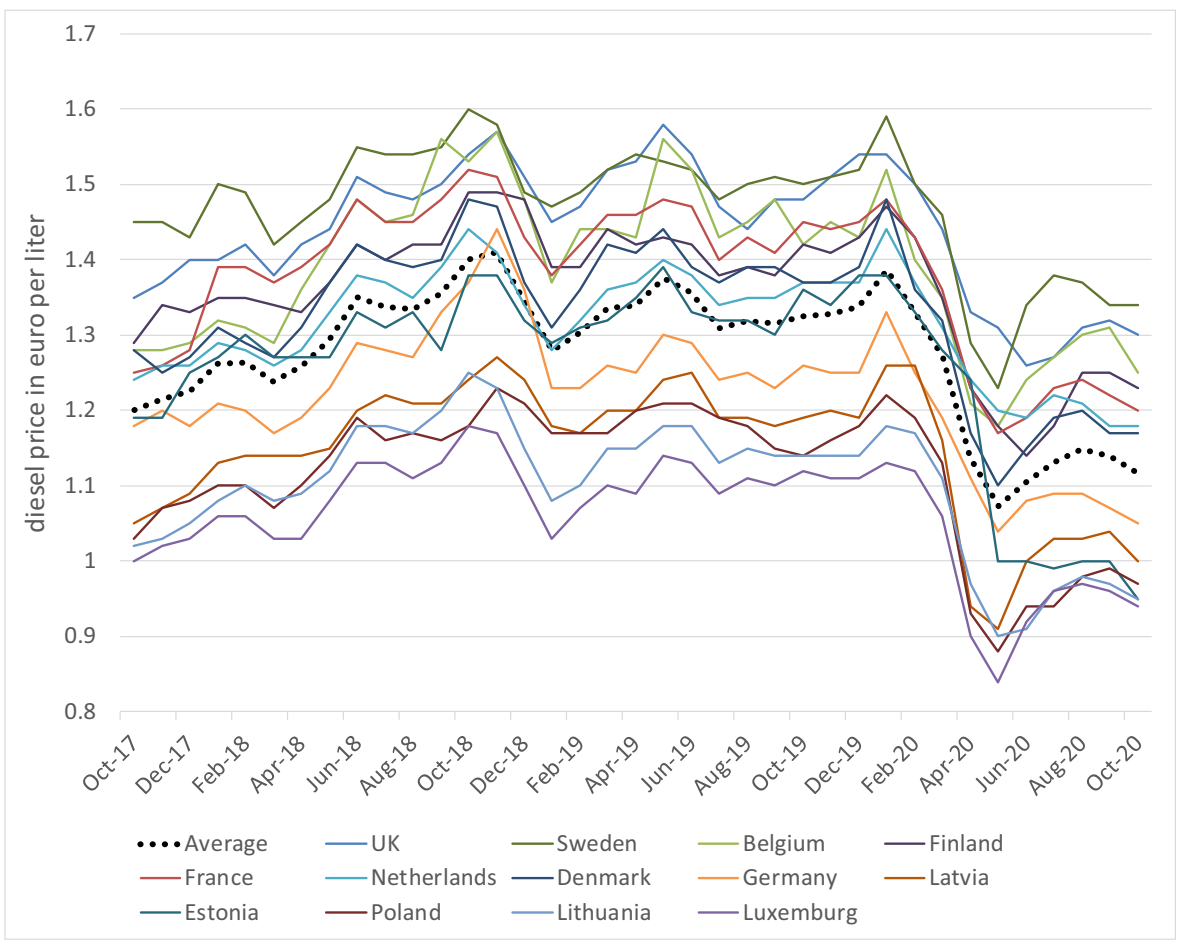

Fig. 3 Price evolution of diesel in 13 north European countries, in euro per litre (inclusive of duties and taxes), Oct 2017-Oct 2020. Note: prices on 6th day of each month. Source: own compilation based on data 'Weekly Oil Bulletin,' Directorate-General Energy-European Commission

The fuel consumption of heavy trucks is affected by the vehicle/engine characteristics (such as engine power, vehicle resistance force and drag coefficient), the vehicle mass and load factor, the topology and road conditions (e.g. flat vs. mountainous, road surface type and conditions, traffic jams and altitude), speed variability, driving style and vehicle age. Trucks are on average 12.4 years old in the European Union. In north Europe, the youngest fleets can be found in Luxemburg (average of 6.5 years), UK (7.4), France (7.2), the Netherlands (9.1) and Germany (9.5). Estonia and Belgium record the highest average truck ages in north Europe, respectively 18.2 and 15.9 years (based on figures ACEA 2019). When it comes to speed, the fuel consumption model for heavy duty diesel trucks developed by Wang and Rakha (2017) shows that the optimum fuel economy cruise speed ranges between 32 and $52 \mathrm{~km} / \mathrm{h}$ for all test vehicles. Steeper roads and heavier vehicles result in lower optimum cruise speeds. The American Trucking Association (ATA) argues a truck driving $75 \mathrm{mph}$ consumes $27 \%$ more fuel than one driving $65 \mathrm{mph}$. The behaviour of the driver can have a large impact on the fuel economy: excessive speed, aggressive driving, unnecessary idling, bad tires conditions or low inflation levels and excessive use of cooling or heating in the cabin increase fuel consumption.

\subsection{Comparing bunker fuel for vessels and diesel for trucks}

Compared to diesel for trucks, the price evolution for marine fuel oils is more in line with the oil price (Fig. 4). The impact of oil price increases on the bunker cost for 


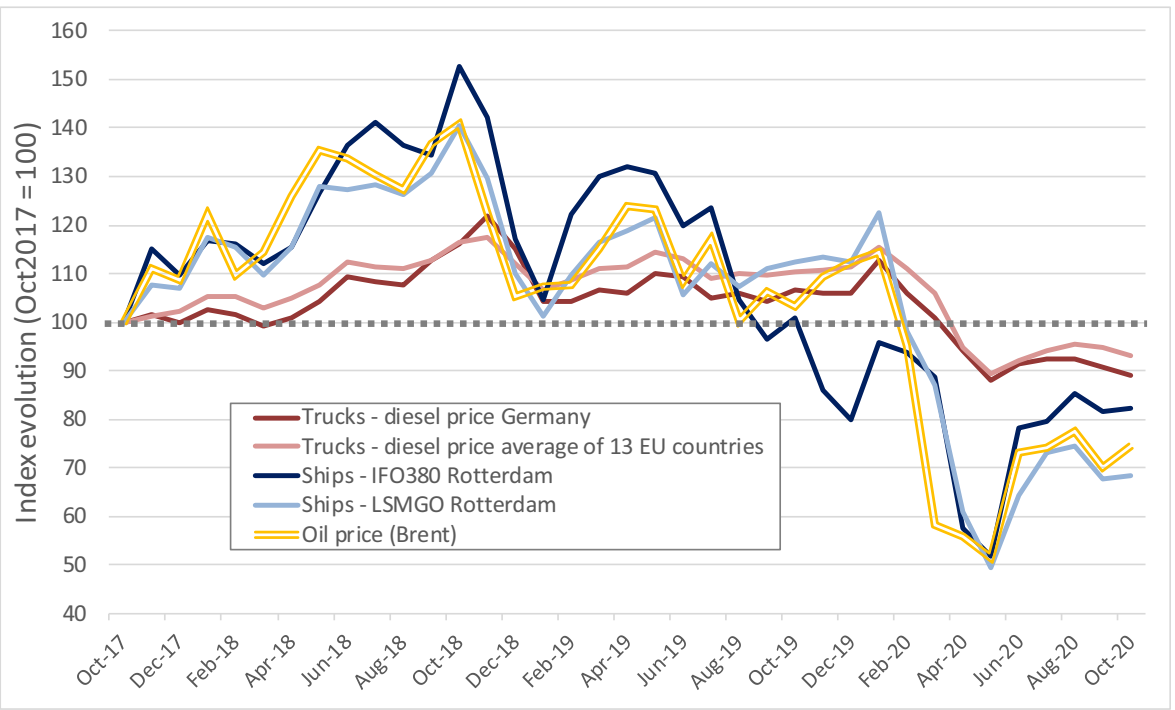

Fig. 4 Recent indexed price evolution of diesel for trucks, bunker fuel for vessels and crude oil (Brent), Oct $2017=$ index 100. Source: own compilation based on data Figs. 1 and 2 and oil price data

shipping is much more direct than in the case of trucking as a large part of the diesel price consists of duties and taxes. However, in the months before the implementation of the $0.5 \%$ global sulphur cap regulation in January 2020, both the price of IFO380 and low sulphur alternatives were heavily affected by speculation and uncertainty, leaving many shipping lines still indecisive on whether to switch to low sulphur fuel or to install emission control devices such as scrubbers.

\section{Impact of fuel costs on operating costs}

\subsection{Fuel costs for roro/ropax vessels in the ECAs}

Bunkers represent a considerable cost factor to shipping lines (Notteboom and Vernimmen 2009). Using the fuel consumption data presented in Fig. 2, we estimate the total fuel cost as a function of sailing distance for three points of observation: October 2018 (i.e. peak in bunker prices since October 2017, see Fig. 1), May 2020 and July 2008. The figures for July 2008 have been added for reference only and to facilitate a comparison with the findings in Notteboom (2011). Table 1 gives the fuel

Table 1 Price per ton of IFO380 and MGO

\begin{tabular}{lllllll}
\hline & $\begin{array}{l}\text { IFO380, } \\
\text { May 2020 }\end{array}$ & $\begin{array}{l}\text { MGO, } \\
\text { May 2020 }\end{array}$ & $\begin{array}{l}\text { IFO380, } \\
\text { Oct 2018 }\end{array}$ & $\begin{array}{l}\text { MGO, } \\
\text { Oct 2018 }\end{array}$ & $\begin{array}{l}\text { IFO380, } \\
\text { July 2008 }\end{array}$ & $\begin{array}{l}\text { MGO, } \\
\text { July 2008 }\end{array}$ \\
\hline USD & 163 & 236 & 479 & 708 & 707 & 1232 \\
Euro & 151 & 219 & 417 & 616 & 447 & 780 \\
\hline
\end{tabular}

Data relates to spot rates in Rotterdam on May 6, 2020; October 5, 2020; and July 18, 2008 
prices for IFO380 and MGO in USD and euro. As mentioned earlier, the price differences between MGO, LSMGO, ULSFO and VLSFO have been very small in recent years, so we use the MGO price as a proxy for the price level of also LSMGO, ULSFO and VLSFO.

May 2020 represents the lowest fuel prices since mid-2005. IFO380 spot prices fluctuated in the USD 100-200 range between 2000 and 2005 and USD 50-150 in the 1990s. The bunker prices of July 18, 2008 (on an USD basis) were among the highest ever recorded, both for IFO380 and MGO. Similar peak prices were only achieved in the spring of 2012. After the peak in the summer of 2008, the IFO380 price declined sharply to reach less than USD 200 at the end of 2008. The price levels gradually recovered after 2009. The period 2011-mid-2014 brought high IFO380 price levels of USD 550 to 700 . By early 2015, the price dropped to below USD 300 as a result of a sudden drop in the oil price in the second half of 2014. Figure 1 depicted the more recent price evolution.

Using ship costs data provided by two roro/ropax operators, Table 2 presents the share of bunker costs in total ship costs for a sample of 15 shortsea liner services operated in the SECAs. For confidentiality reasons, the origin-destinations pairs are not listed in the table, only the service's submarket and distance class. Total ship costs are the sum of bunker costs and other vessel costs. In order to be able to compare ship costs between vessel types/sizes and routes, the ship cost data was collected in euro per lane metre of capacity per nautical mile. The share of fuel costs depends on the applicable bunker cost per ton: it will be high when fuel prices are high and lower when fuel prices are low.

The results slightly differ between services even in the same submarket (see e.g. routes 9 and 10). The differences are caused by a complex interaction between fleet composition, vessel capacities, vessel age and other operational characteristics of the observed liner services. When using IFO380, the average share of bunkers in total ship costs amounted to $19.7 \%$ in May 2020 (with a lowest value of $13.2 \%$ for the ultra-short routes and a highest share of 28.3\%), 40.1\% in October 2018 (with shares ranging between 29.5 and $52.1 \%$ ) and $41.8 \%$ in July 2018 (31 to 54\%). The use of MGO increases the average share of fuel costs to $26.2 \%, 49.6 \%$ and $55.4 \%$ respectively. Figure 5 provides an overview of the increase in total ship costs when using MGO (or LSMGO/ULSFO/VLSFO with a similar price level) instead of IFO380. In May 2020, the price gap between IFO380 and MGO was narrow, so using MGO only led to an average increase in overall ship costs of $8.9 \%$. In July 2008, the price gap between IFO380 and MGO was significant, resulting in a hefty $31.1 \%$ increase in ship costs on average when using MGO instead of IFO380, with a peak of over $40 \%$ for route 10 . The results of October 2018 lie in between the July 2008 and May 2020 figures. As expected, the impact of the compulsory use of low sulphur fuel on the overall ship costs for roro/ropax services in northern Europe is very dependent on the absolute bunker price levels and the relative price gaps between different fuel types.

\subsection{Fuel cost for trucks}

Diesel is subject to less price volatility compared to marine fuels (see Fig. 4 earlier). This implies that the share of fuel costs in the total operating costs of a truck fleet is less affected by the absolute diesel prices. An example for trucking on routes to/from Belgium is presented in Fig. 6. While in shipping, the share of bunker costs in total 
Table 2 Share of bunker costs in total ship costs for two fuel types: IFO380 (1.5\%) and MGO $(0.1 \%)$ - shortsea vessels with an average commercial speed of 18.5 knots

\begin{tabular}{|c|c|c|c|c|c|c|c|c|}
\hline \multirow{2}{*}{\multicolumn{2}{|c|}{ Submarket }} & \multirow{3}{*}{$\begin{array}{l}\begin{array}{l}\text { Distance } \\
\text { class }\end{array} \\
>750 \mathrm{~km}\end{array}$} & \multicolumn{6}{|c|}{ Share of bunker costs in total operating costs (bunker + vessel costs) } \\
\hline & & & \multirow{2}{*}{$\begin{array}{l}\text { IFO380, } \\
\text { May 2020 } \\
18.6 \%\end{array}$} & \multirow{2}{*}{$\begin{array}{l}\text { MGO, } \\
\text { May 2020 }\end{array}$} & \multirow{2}{*}{$\begin{array}{l}\text { IFO380, } \\
\text { Oct 2018 } \\
38.7 \%\end{array}$} & \multirow{2}{*}{$\begin{array}{l}\text { MGO, } \\
\text { Oct 2018 } \\
48.2 \%\end{array}$} & \multirow{2}{*}{$\begin{array}{c}\text { IFO380, } \\
\text { July } 2008\end{array}$} & \multirow{2}{*}{$\begin{array}{l}\begin{array}{l}\text { MGO, } \\
\text { July } 2008\end{array} \\
54.1 \%\end{array}$} \\
\hline $\begin{array}{c}\text { Route } \\
1\end{array}$ & $\begin{array}{c}\mathrm{UK} / \mathrm{LH}-\mathrm{H} \\
\text { range }<-> \\
\text { Baltic }\end{array}$ & & & & & & & \\
\hline $\begin{array}{c}\text { Route } \\
2\end{array}$ & $\begin{array}{c}\mathrm{UK} / \mathrm{LH}-\mathrm{H} \\
\text { range }<-> \\
\text { Baltic }\end{array}$ & $>750 \mathrm{~km}$ & $19.2 \%$ & $25.6 \%$ & $39.6 \%$ & $49.2 \%$ & $41.3 \%$ & $55.1 \%$ \\
\hline $\begin{array}{c}\text { Route } \\
3\end{array}$ & $\begin{array}{c}\mathrm{UK} / \mathrm{LH}-\mathrm{H} \\
\text { range }<-> \\
\text { Baltic }\end{array}$ & $>750 \mathrm{~km}$ & $19.5 \%$ & $26.0 \%$ & $40.1 \%$ & $49.7 \%$ & $41.8^{*}$ & $55.6 \%$ \\
\hline $\begin{array}{c}\text { Route } \\
4\end{array}$ & $\begin{array}{l}\mathrm{UK}<->\mathrm{LH}-\mathrm{H} \\
\quad \text { range }\end{array}$ & $400-750 \mathrm{~km}$ & $24.2 \%$ & $31.6 \%$ & $46.8 \%$ & $56.5 \%$ & $48.6 \%$ & $62.2 \%$ \\
\hline $\begin{array}{c}\text { Route } \\
5\end{array}$ & $\begin{array}{c}\mathrm{UK} / \mathrm{LH}-\mathrm{H} \\
\text { range }<-> \\
\text { Baltic }\end{array}$ & $>750 \mathrm{~km}$ & $22.3 \%$ & $29.4 \%$ & $44.3 \%$ & $54.0 \%$ & $46.0 \%$ & $59.8 \%$ \\
\hline $\begin{array}{c}\text { Route } \\
6\end{array}$ & $\begin{array}{l}\mathrm{UK} / \mathrm{LH}-\mathrm{H} \\
\text { range }<-> \\
\text { Baltic }\end{array}$ & $400-750 \mathrm{~km}$ & $19.8 \%$ & $26.3 \%$ & $40.5 \%$ & $50.1 \%$ & $42.2 \%$ & $56.0 \%$ \\
\hline $\begin{array}{c}\text { Route } \\
7\end{array}$ & $\begin{array}{c}\mathrm{UK} / \mathrm{LH}-\mathrm{H} \\
\text { range }<-> \\
\text { Baltic }\end{array}$ & $400-750 \mathrm{~km}$ & $14.3 \%$ & $19.5 \%$ & $31.6 \%$ & $40.6 \%$ & $33.1 \%$ & $46.4 \%$ \\
\hline $\begin{array}{c}\text { Route } \\
8\end{array}$ & $\begin{array}{c}\mathrm{UK} / \mathrm{LH}-\mathrm{H} \\
\text { range }<-> \\
\text { Baltic }\end{array}$ & $400-750 \mathrm{~km}$ & $21.9 \%$ & $28.9 \%$ & $43.6 \%$ & $53.4 \%$ & $45.4 \%$ & $59.2 \%$ \\
\hline $\begin{array}{c}\text { Route } \\
9\end{array}$ & Intra-Baltic & $>750 \mathrm{~km}$ & $21.2 \%$ & $28.1 \%$ & $42.7 \%$ & $52.4 \%$ & $44.4 \%$ & $58.2 \%$ \\
\hline $\begin{array}{c}\text { Route } \\
10\end{array}$ & Intra-Baltic & $>750 \mathrm{~km}$ & $28.3 \%$ & $36.4 \%$ & $52.1 \%$ & $61.6 \%$ & $53.8 \%$ & $67.0 \%$ \\
\hline $\begin{array}{c}\text { Route } \\
11\end{array}$ & Intra-Baltic & $400-750 \mathrm{~km}$ & $19.0 \%$ & $25.4 \%$ & $39.3 \%$ & $48.9 \%$ & $40.9 \%$ & $54.7 \%$ \\
\hline $\begin{array}{c}\text { Route } \\
12\end{array}$ & Intra-Baltic & $400-750 \mathrm{~km}$ & $22.7 \%$ & $29.9 \%$ & $44.8 \%$ & $54.5 \%$ & $46.5 \%$ & $60.3 \%$ \\
\hline $\begin{array}{c}\text { Route } \\
13\end{array}$ & Intra-Baltic & $400-750 \mathrm{~km}$ & $17.7 \%$ & $23.8 \%$ & $37.3 \%$ & $46.8 \%$ & $39.0 \%$ & $52.7 \%$ \\
\hline $\begin{array}{c}\text { Route } \\
14\end{array}$ & Intra-Baltic & Ultra-short & $13.2 \%$ & $18.0 \%$ & $29.5 \%$ & $38.2 \%$ & $31.0 \%$ & $43.9 \%$ \\
\hline $\begin{array}{l}\text { Route } \\
15\end{array}$ & Intra-Baltic & Ultra-short & $13.8 \%$ & $18.8 \%$ & $30.6 \%$ & $39.4 \%$ & $32.1 \%$ & $45.2 \%$ \\
\hline Average & & & $19.7 \%$ & $26.2 \%$ & $40.1 \%$ & $49.6 \%$ & $41.8 \%$ & $55.4 \%$ \\
\hline Standarc & d deviation & & $4.0 \%$ & $4.9 \%$ & $6.2 \%$ & $6.5 \%$ & $6.3 \%$ & $6.4 \%$ \\
\hline High & & & $28.3 \%$ & $36.4 \%$ & $52.1 \%$ & $61.6 \%$ & $53.8 \%$ & $67.0 \%$ \\
\hline Low & & & $13.2 \%$ & $18.0 \%$ & $29.5 \%$ & $38.2 \%$ & $31.0 \%$ & $43.9 \%$ \\
\hline
\end{tabular}

Source: own elaboration based on data provided by ship operators

$\mathrm{LH}-\mathrm{H}=$ ports in the Le Havre-Hamburg range, a port range containing all seaports along the coastline between Hamburg in Germany and Le Havre in France 


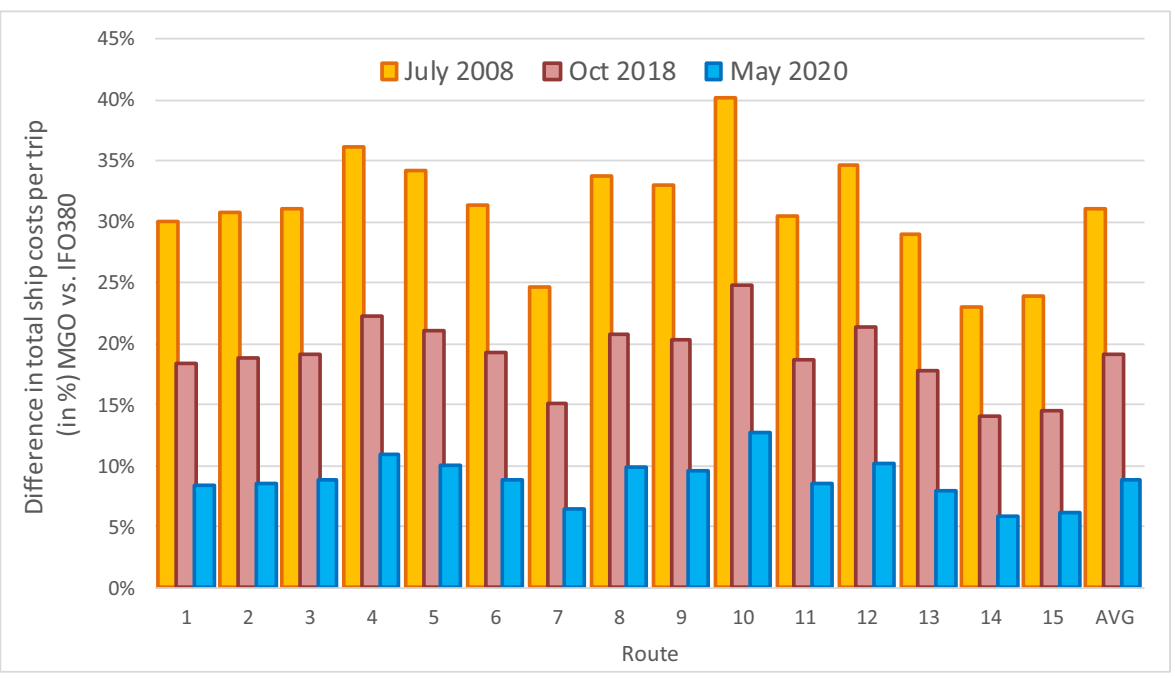

Fig. 5 Increase in total ship costs as a result of the use of MGO $(0.1 \%)$ instead of IFO380 (1.5\%) - shortsea vessels with an average commercial speed of 18.5 knots. Source: own elaboration based on data provided by ship operators

vessel costs decreased with more than $20 \%$ points when comparing July 2008 to May 2020 (Table 2), and the relative share of fuel costs in total truck costs only showed a drop of 7 to $9 \%$ points.

In the past decades, truck manufacturers have achieved continuous improvements in fuel economy and emissions partly driven by ever stricter regulation. The European Commission introduced heavy-duty emission standards in 1988 with Directive 88/77/ EEC. Euro I standards were introduced in 1992, followed by the introduction of Euro II standards in 1996. These standards applied among others to truck engines but were

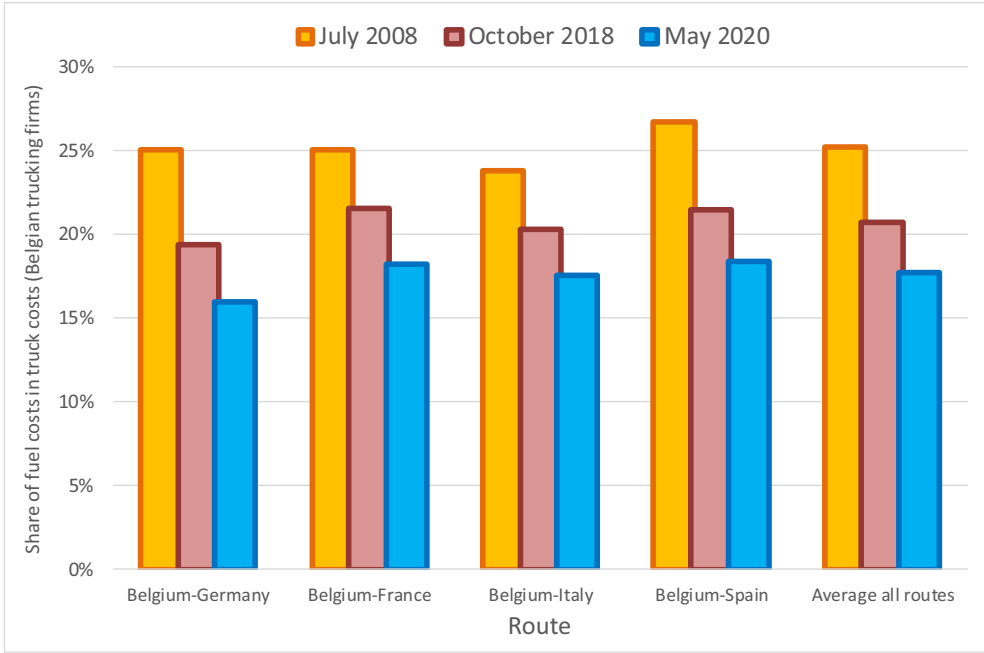

Fig. 6 Average share of fuel costs in truck costs for Belgian road haulage companies. Source: own compilation based on figures of ITLB (Institute Road Transport and Logistics Belgium) - and former IWT (Institute for Road Transport for figures 2008) 
voluntary. Euro III standards were introduced in 2000 and Euro IV/V standards in 2005 and 2008. Euro VI emission standards were introduced in 2009 by Regulation 595/ 2009 followed by further specifications and amendments. The new emission limits were implemented from 2013/2014. Compared to roro/ropax operators, the road haulage sector shows much more flexibility in adapting to changing rules regarding fuel economy and emissions. One of the reasons is that trucks are amortized over a period of only 4 to 5 years, while in shipping vessels have a much longer lifecycle, typically 20 to 25 years. In other words, it only takes a few years for the trucking industry to renew a fleet, while in shipping, much more time is needed. The result is that energy efficiency gains due to new technologies develop rather fast in the trucking industry. In the shipping industry, measures to improve fuel efficiency in the short term are focused on the existing fleet (e.g. switch to other fuel type or reduced speed), while a replacement of the entire fleet by more fuel efficient and clean vessels implies a longterm investment program.

\section{Comparative cost analysis on origin-destination pairs}

\subsection{Selection of origin-destination relations in north Europe}

The remainder of the paper focuses on a detailed cost analysis to assess modal competition between the roro/truck option and the 'truck only' option against the background of different fuel cost situations and the use of MGO (0.1\% sulphur content) versus IFO380 (1.5\%). In line with Notteboom (2011), we focus on thirty origindestination routes in north Europe. All shortsea solutions on these routes potentially face competition from a 'truck only' option. The 'truck only' option means that a truck is used all the way from origin to destination without including a shortsea section. For each route, several alternatives to the 'truck only' option are presented combining long, medium or short roro/ropax connections with a pre- and/or endhaul by truck. The thirty origin-destination pairs belong to four groups of routes:

- Group 1: Germany/Denmark to Sweden (see map in Fig. 9 in Appendix)

- Group 2: the English Channel (see Fig. 10 in Appendix). The 'truck only' option in relation to traffic with the UK includes a short rail section via the Channel Tunnel.

- Group 3: west Europe to Baltic States (see Fig. 11 in Appendix)

- Group 4: west Europe to Scandinavia (Sweden/Norway) (see Fig. 12 in Appendix)

\subsection{Cost model specification}

The route cost model used takes the following simple form:

$$
\mathrm{C}_{\mathrm{i}}=\mathrm{c}_{\text {truck }} \cdot \mathrm{D}_{\text {truck }}+\mathrm{c}_{\text {roro }} \cdot \mathrm{D}_{\text {roro }}+\mathrm{c}_{\text {charge }}+\mathrm{c}_{\text {crossing }}
$$

with

$C_{i} \quad$ total cost per truckload for origin-destination route $i$ 
$c_{\text {truck }} \quad$ cost per vehicle-kilometre (truck) for road sections of route $i$ (excluding road charges and fixed crossing fees)

$D_{\text {truck }} \quad$ road distance in kilometre on route $i$

$c_{\text {roro }} \quad$ cost per vessel kilometre per 17 lane metre for sailing sections of route $i$ (truck equivalent)

$D_{\text {roro }} \quad$ roro/ferry sailing distance in kilometre on route $i$

$c_{\text {charge }}$ one-way total road charges (e.g. péage, kilometre charges and LKW-Maut) on route $i$.

$c_{\text {crossing }}$ one-way total tariff for fixed crossings by truck, if any (e.g. Channel Tunnel, Fernbelt and Öresund)

The road distance $D_{\text {truck }}$ was obtained by using a route planner. The sailing distance $D_{\text {roro }}$ for shortsea vessels is based on the maritime distance calculator available at Dataloy (www.dataloy.com). The distances per origin-destination relations are presented in Table 3. For the highways, the average driving speed is set at $80 \mathrm{~km} / \mathrm{h}$, for other roads $65 \mathrm{~km} / \mathrm{h}$. The commercial speed of roro/ropax vessels in this analysis amounts to $18.5 \mathrm{knots}(34.3 \mathrm{~km} / \mathrm{h})$.

The unit rates per kilometre ( $c_{\text {truck }}$ and $c_{\text {roro }}$ ) are based on the cost functions for trucks and shortsea vessels. The cost bases of trucking firms can vary considerably. Some of the cost factors are linked to the country where the company/truck and the driver are registered (e.g. tax regime, driver wages and vehicle tax), while other costs are more related to the territory where the truck is being deployed (e.g. differences in fuel price between countries of operation, see Fig. 3). To differentiate between truck cost levels throughout northern Europe, we consider four cost groups for a heavy truck of Euro VI class with an average cargo load of 12 to 18 t: (a) Benelux countries, France and Germany; (b) Eastern Germany and Poland; (c) the UK and (d) the Baltic States and Russia. The base costs for trucking companies were derived from data obtained from market players and updated from the figures included in Notteboom (2011). Figure 7 depicts the truck cost functions per kilometre for October 2018 (high fuel price) and May 2020 (low fuel price). Shorter distances show a higher unit cost per kilometre given the existence of a fixed truck deployment fee irrespective of the transport distance (payload) covered. The longer the distance, the less impact the fixed fee will have on the total cost per kilometre. The overall cost per vehicle-kilometre considers the estimated nationality distribution of trucks operational on each of the four main shortsea markets in north Europe (Table 8 in Appendix).

$C_{\text {truck }}$ does not include the cost trucks incur when using fixed crossings such as bridges or tunnels. Cost factor $c_{\text {crossing }}$ reflects the additional truck cost when using such fixed links. On the English Channel, ferries face stiff competition from the Eurotunnel for manned truck/trailer combinations. Eurotunnel Le Shuttle Freight offers shuttles dedicated to trucks and can transport up to 30 trucks in semi-enclosed waggons. Trucks cross the straits in $90 \mathrm{~min}$. The regular tariff for trailer combination of more than $13 \mathrm{~m}$ is dependent on the travel date, but typically ranges between 300 and 350 euro excl. VAT (rates in Autumn 2020, one-way, excluding discounts, online booking system www.eurotunnelfreight.com). Eurotunnel offers competitive rates to large hauliers, but under very restrictive terms - a very good price for prebooked slots on nominated shuttles, but punitively high charges for spot bookings (or last-minute changes). The ferries, by contrast, offer more flexibility ('turn up and go when you want'). The fixed 


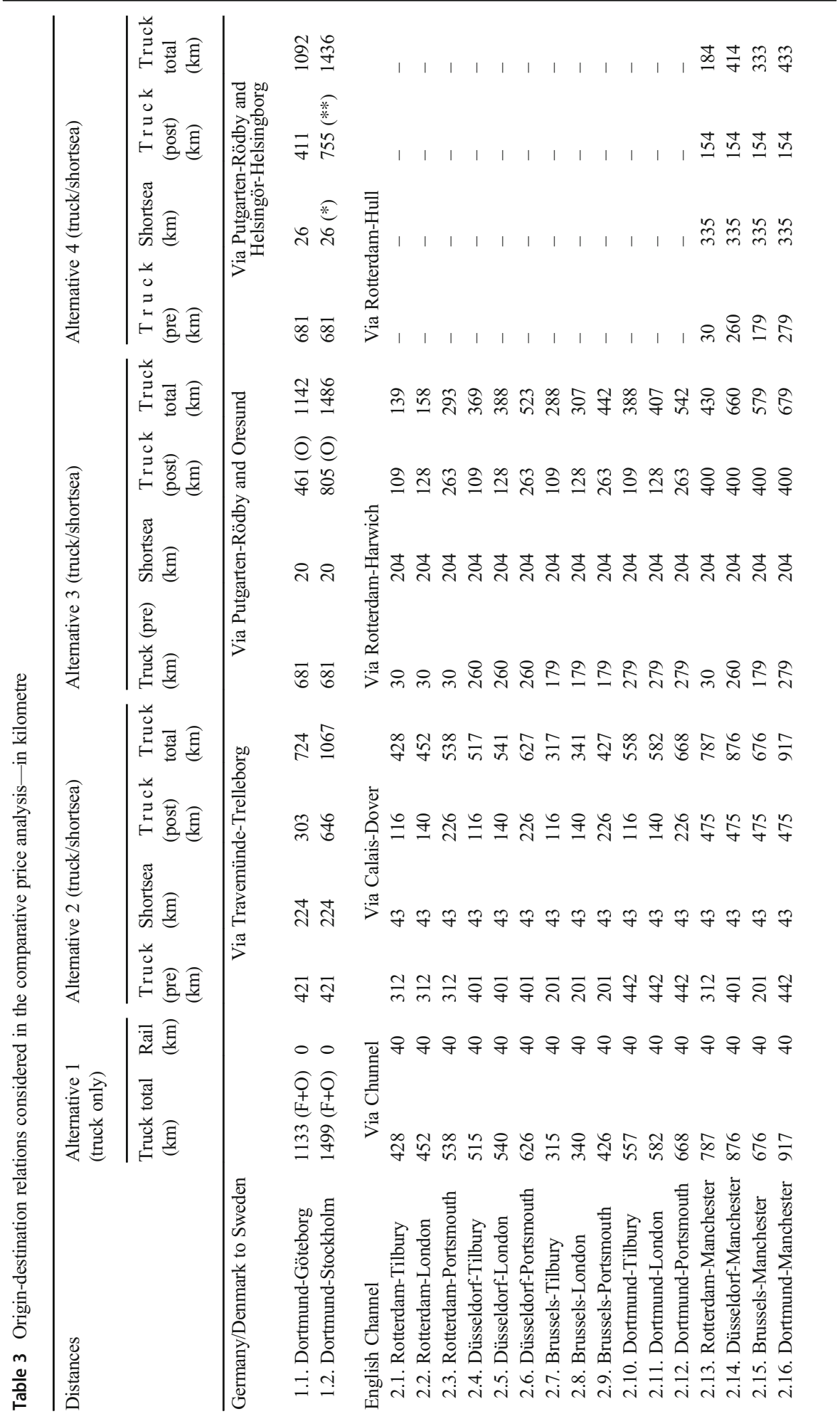




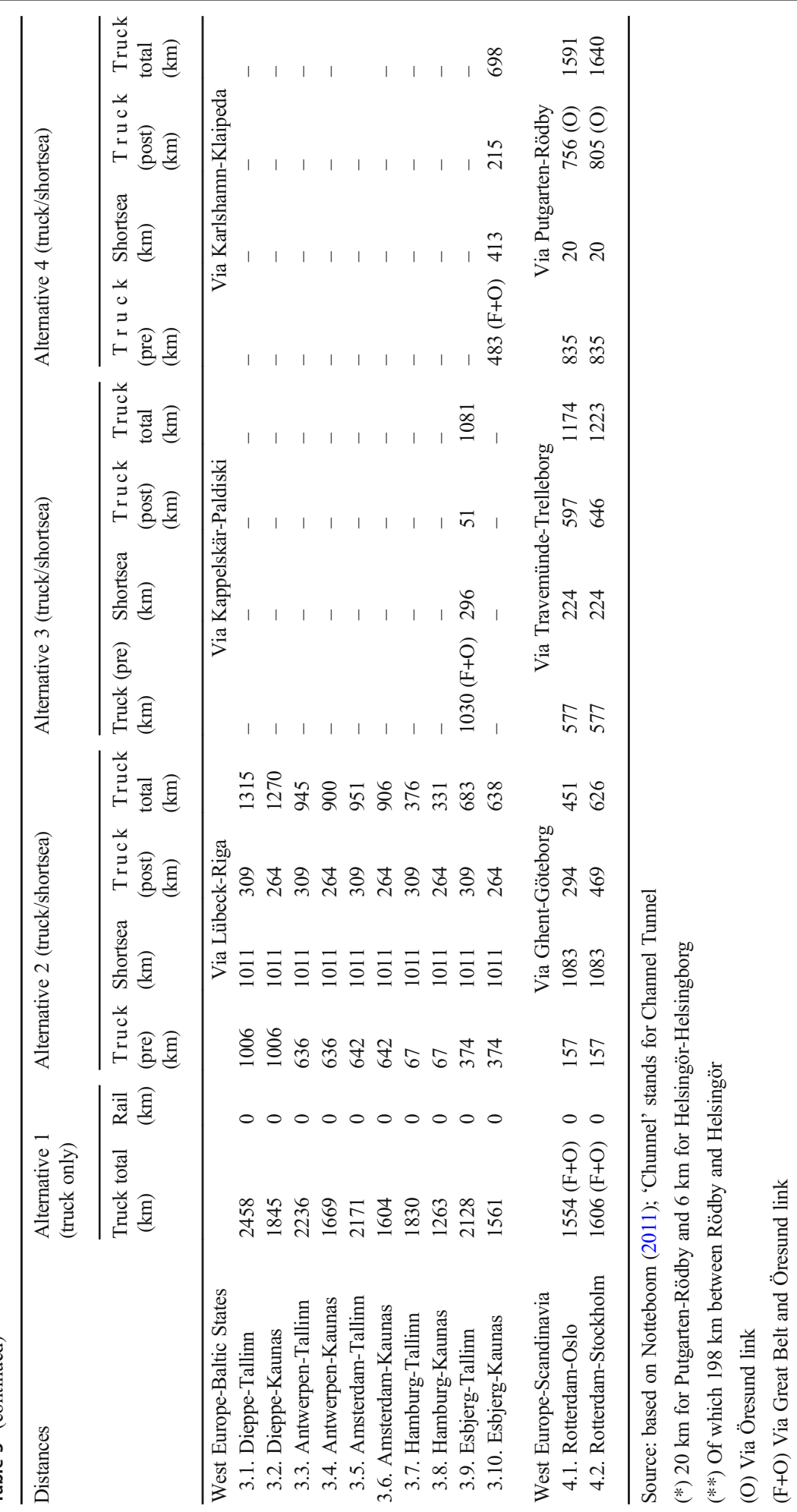



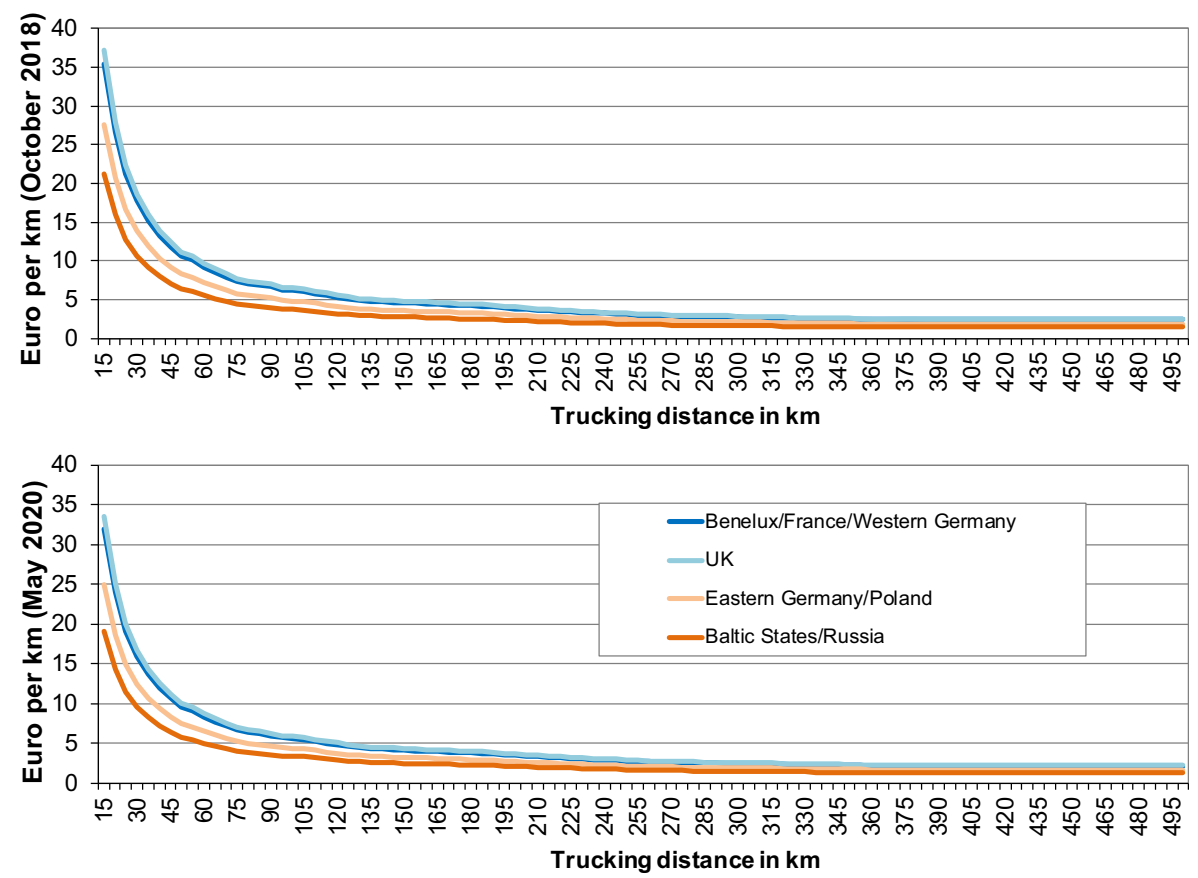

Fig. 7 Cost functions for road haulage (in euro per kilometre)- October 2018 (top) and May 2020 (bottom). Source: own compilation based on market data

links in Denmark (Great Belt link and Oresund link) make it possible for truck drivers to drive from the European mainland to Sweden and Norway. The use of these fixed links is not free of charge. The full price for using the Oresund link with a truck/trailer combination is 161 euro (excluding VAT) at the toll station and 149 euro for an online ticket (figures October 2020). Significant discounts apply to most of the trucking companies frequently making the crossing using a Bropas Business. Prices range from 69.7 euro per crossing in case of 1-500 single trips per year up to 59.20 euro per crossing in case of more than 10,000 single trips per year (see www.oresundsbron.com). In our analysis, we use 110 euro as an average base rate for trucks passed on to the customer. Another important fixed link is the Great Belt fixed link connecting the Danish towns of Korsør and Nyborg on the islands of Zealand (Sjælland) and Fyn (or Funen) respectively. The 2020 toll fees for trucks (10-19 m) amount to 135 euro incl. VAT (one way, figures www. storebaelt.dk, excluding discounts) or 112 euro excl. VAT. In our analysis, we use a market-based fee of 112 euro per transit. A combined use of the Oresund link and the Great Belt link thus costs about 222 euro (excl. VAT) on average.

$C_{\text {truck }}$ also does not include applicable tolls, kilometre fees and other additional road or congestion charges (i.e. $\operatorname{cost}$ factor $c_{\text {charge }}$ ). The situation in northern Europe is quite complex. Trucks using the road network in the Netherlands, Luxemburg, Denmark and Sweden need to have a Eurovignet onboard. For trucks of emission class Euro VI class and with four or more axles, the annual tariff for a Eurovignet is 1250 euro (figures 2020). For applicable routes, we assume that trucks drive on average $20,000 \mathrm{~km}$ per year on roads subjected to the Eurovignet, which results in 0.0625 euro per kilometre. Belgium used to be one of the Eurovignet countries till 2016. The country now applies 
a kilometre charge on the highway network. For Euro VI trucks of 12 to 32 t, the 2020 charge amounted to 0.132 euro per kilometre (Flanders, Wallonia and highway network around Brussels, data from www.viapass.be). Germany charges a so-called LKW-Maut for trucks using the main roads. The price level of the LKW-Maut depends on the emission class of the truck, the weight class and the number of axles. For example, a Euro VI truck between 12 and $18 \mathrm{t}$ pays 0.128 euro per kilometre, while a 4-axle truck of more than $18 \mathrm{t}$ is charged 0.198 euro per kilometre (data provided by www.tollcollect.de). A large part of the highway network in France consists of toll roads ('péage'). The toll fees are revised every year and differ from road section to road section, so there is no standard fee per kilometre. Given the complexity of road charging practices across north European road networks, the total road charge cost per origin-destination relation was calculated using the road fee output of the professional route planner Impargo (www.impargo.de). Also here, we used trailer combination of Euro VI class with an average cargo load of 12 to $18 \mathrm{t}$.

$C_{\text {roro }}$ is the cost per kilometre incurred by a truck/trailer combination (equivalent to a vessel slot of 17 lane metre capacity) when using a shortsea service. Market data on the 17 roro/ropax services in the sample formed the basis for the estimation of a lower and upper limit to the unit cost per kilometre of sailing distance. These upper and lower limits do not assume full capacity use, but instead consider data obtained from shortsea operators on the average utilization degree of the vessels compared to the total lane metre capacity operating on each of the 17 routes. The average two-way vessel utilization degree reached more than $70 \%$ in October 2018 with a lowest value of $57 \%$ and a highest value of $91 \%$. Short routes typically have a lower vessel utilization. In the analysis, we used $40 \%$ utilization for ultra-short routes $(<50 \mathrm{~km}), 55 \%$ for short routes $(50-125 \mathrm{~km}), 60 \%$ for medium long routes $(125-400 \mathrm{~km})$ and $75 \%$ for long routes $(>400 \mathrm{~km})$. Later in this paper, a sensitivity analysis will measure the impact of lower utilization levels on the shortsea unit cost per kilometre. Figure 8 presents four curves for October 2018 and May 2020: upper and lower curves when using HFO $(1.5 \%)$ and upper and lower curves when using MGO $(0.1 \%)$. The costs per kilometre for shorter distances are much higher since vessel load factors are lower and fixed costs (such as port dues) have a large impact on the cost structure on short distances.

\subsection{Cost model output-impact of the use of low sulphur fuel on route cost}

The model output makes it possible to measure the impact of the switch to low sulphur fuel on the total cost per routing alternative (combined truck/shortsea options) on each of the thirty origin-destination relations for October 2018 (high fuel prices) and May 2020 (low fuel prices) (see Tables 4 and 5). On origin-destination relations with an ultra-short or short maritime section (Calais-Dover, Putgarten-Rödby, HelsingörHelsingborg and Travemünde-Trelleborg), the total cost increase for the entire route including sections by vessel and truck ranges from 0.5 to $4.2 \%$ for October 2018 and only 0.2 to $1.3 \%$ for May 2020. The more important the shortsea section is in the total transport distance, the more impact the use of low sulphur fuel has on the total price for the truck/shortsea option. For example, on the Rotterdam-Oslo route (no. 4.1), the cost increase associated with the shift from HFO to MGO reaches about 6 to $7 \%$ in October 2018 when using the Ghent-Göteborg shortsea link. When using shorter shortsea links (alternatives 3 and 4), the price increase ranges between 0.5 and $1.5 \%$. In the case of the 


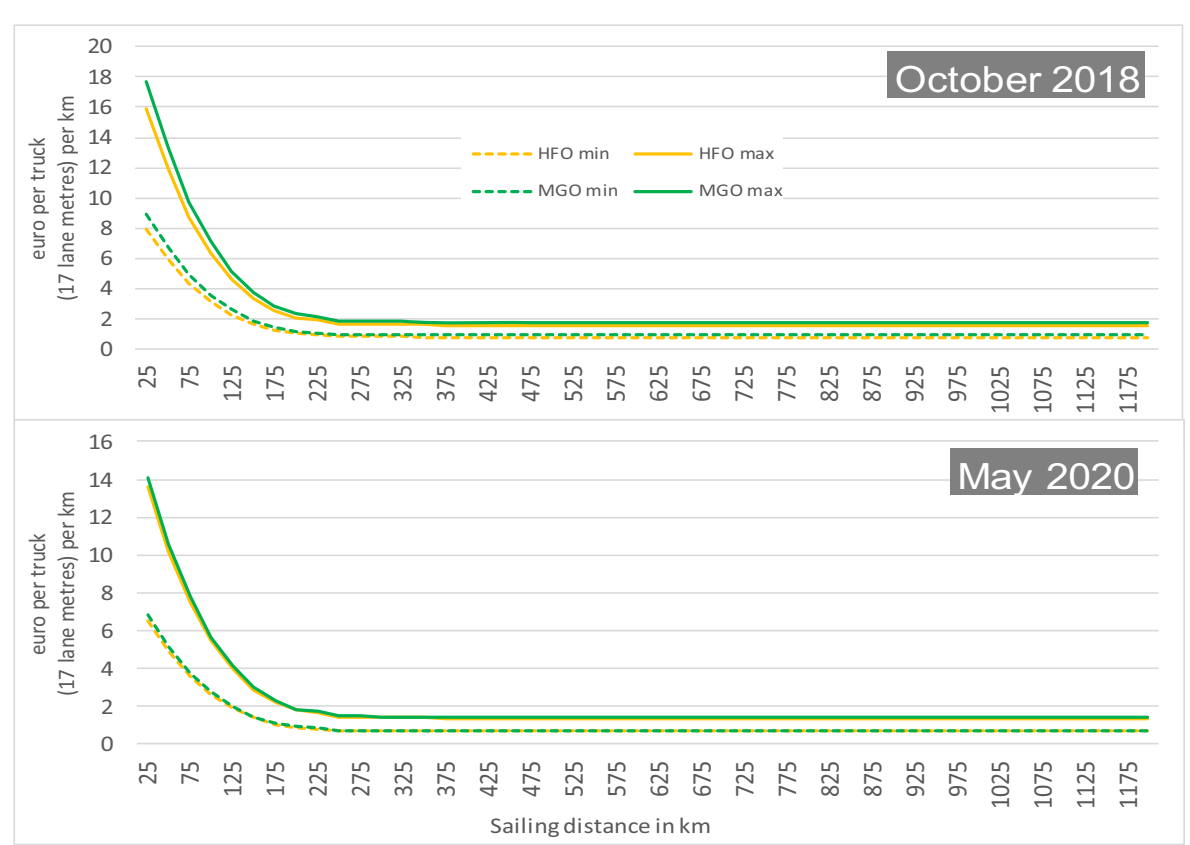

Fig. 8 Roro/ropax services: upper and lower cost in euro per truck shipped per kilometre sailing distance-October 2018 (top) and May 2020 (bottom). Source: own compilation based on market data

Hamburg-Tallinn connection, using low sulphur fuel on the shortsea service between Lübeck and Riga even increases the total route cost in October 2018 by 7 to $8 \%$. Thus, as expected, the use of low sulphur fuels particularly has an impact on the origindestination relations with a medium or long shortsea section. The cost changes for May 2020 (Table 5) are much smaller given the lower fuel prices and small price differential between IFO380 and low sulphur fuels (Fig. 1).

\subsection{Cost model output-impact on competition between routing options}

The cost model output in Tables 4 and 5 points to rather low cost increase percentages when using low sulphur fuel, i.e. typically a few percent with a few cases up to $8 \%$ for October 2018. Still, even small changes can have an impact on the relative cost competitiveness of different routing options. The model output makes it possible to compare the 'truck only' option with one or more combined truck/shortsea options on each of the thirty origin-destination relations for October 2018 (high fuel prices) and May 2020 (low fuel prices). Table 6 summarizes the model output by comparing the 'truck only' route option (alternative 1) to the other routing alternatives involving a short or long shortsea section. The cost differences are presented for the use of IFO380 $(1.5 \%)$ and MGO $(0.1 \%)$ on the shortsea services.

In quite a few cases, one of the shortsea alternatives remains by far the most preferred option even when considering the use of low sulphur fuel. On the trade lane between Germany/Denmark and Sweden, the Travemünde-Trelleborg ferry connection has a significant cost advantage compared to the 'truck only' option. Trucks typically incur higher costs because of significant additional distances to be travelled and tolls linked to the use of the fixed 
Table 4 Impact of the use of MGO $(0.1 \%)$ instead of HFO (1.5\%) on the total cost per routing alternative - price increase in percent for transport between origin and destination (truck+shortsea) in October 2018 (high fuel prices)

\begin{tabular}{|c|c|c|c|c|c|c|}
\hline & \multicolumn{2}{|c|}{$\begin{array}{l}\text { Alternative } 2 \\
\text { (shortsea+truck) }\end{array}$} & \multicolumn{2}{|c|}{$\begin{array}{l}\text { Alternative } 3 \text { (shortsea+ } \\
\text { truck) }\end{array}$} & \multicolumn{2}{|c|}{$\begin{array}{l}\text { Alternative } 4 \\
\text { (shortsea+truck) }\end{array}$} \\
\hline & roro $\min$ & roro $\max$ & roro $\min$ & roro $\max$ & roro $\min$ & roro $\max$ \\
\hline Germany/Denmark to Sweden & \multicolumn{2}{|c|}{$\begin{array}{l}\text { Via Travemünde- } \\
\text { Trelleborg }\end{array}$} & \multicolumn{2}{|c|}{$\begin{array}{c}\text { Via Putgarten-Rödby and } \\
\text { Oresund }\end{array}$} & \multicolumn{2}{|c|}{$\begin{array}{r}\text { Via P-R and } \\
\text { Helsingör- } \\
\text { Helsingborg }\end{array}$} \\
\hline 1.1. Dortmund-Göteborg & $1.5 \%$ & $2.3 \%$ & $0.7 \%$ & $1.2 \%$ & $1.0 \%$ & $1.6 \%$ \\
\hline 1.2. Dortmund-Stockholm & $1.0 \%$ & $1.6 \%$ & $0.6 \%$ & $0.9 \%$ & $0.8 \%$ & $1.2 \%$ \\
\hline English Channel & \multicolumn{2}{|c|}{ Via Calais-Dover } & \multicolumn{2}{|c|}{ Via Rotterdam-Harwich } & \multicolumn{2}{|c|}{ Via Rotterdam-Hull } \\
\hline 2.1. Rotterdam-Tilbury & $2.6 \%$ & $3.7 \%$ & $3.2 \%$ & $4.4 \%$ & - & - \\
\hline 2.2. Rotterdam-London & $2.4 \%$ & $3.5 \%$ & $3.0 \%$ & $4.2 \%$ & - & - \\
\hline 2.3. Rotterdam-Portsmouth & $2.1 \%$ & $3.1 \%$ & $2.7 \%$ & $3.8 \%$ & - & - \\
\hline 2.4. Düsseldorf-Tilbury & $2.2 \%$ & $3.2 \%$ & $2.5 \%$ & $3.6 \%$ & - & - \\
\hline 2.5. Düsseldorf-London & $2.1 \%$ & $3.1 \%$ & $2.4 \%$ & $3.4 \%$ & - & - \\
\hline 2.6. Düsseldorf-Portsmouth & $1.9 \%$ & $2.8 \%$ & $1.8 \%$ & $2.8 \%$ & - & - \\
\hline 2.7. Brussels-Tilbury & $3.0 \%$ & $4.2 \%$ & $2.7 \%$ & $3.8 \%$ & - & - \\
\hline 2.8. Brussels-London & $3.0 \%$ & $4.2 \%$ & $2.6 \%$ & $3.8 \%$ & - & - \\
\hline 2.9. Brussels-Portsmouth & $2.6 \%$ & $3.7 \%$ & $2.1 \%$ & $3.1 \%$ & - & - \\
\hline 2.10. Dortmund-Tilbury & $2.0 \%$ & $3.0 \%$ & $2.4 \%$ & $3.4 \%$ & - & - \\
\hline 2.11. Dortmund-London & $2.0 \%$ & $3.0 \%$ & $2.3 \%$ & $3.3 \%$ & - & - \\
\hline 2.12. Dortmund-Portsmouth & $1.8 \%$ & $2.7 \%$ & $1.8 \%$ & $2.7 \%$ & - & - \\
\hline 2.13. Rotterdam-Manchester & $1.5 \%$ & $2.3 \%$ & $2.2 \%$ & $3.2 \%$ & $3.4 \%$ & $4.6 \%$ \\
\hline 2.14. Düsseldorf-Manchester & $1.4 \%$ & $2.1 \%$ & $1.5 \%$ & $2.3 \%$ & $2.7 \%$ & $3.9 \%$ \\
\hline 2.15. Brussels-Manchester & $1.7 \%$ & $2.6 \%$ & $1.7 \%$ & $2.6 \%$ & $3.1 \%$ & $4.3 \%$ \\
\hline 2.16. Dortmund-Manchester & $1.3 \%$ & $2.1 \%$ & $1.5 \%$ & $2.3 \%$ & $2.6 \%$ & $3.8 \%$ \\
\hline West Europe-Baltic States & \multicolumn{2}{|c|}{ Via Lübeck-Riga } & \multicolumn{2}{|c|}{ Via Kappelskär-Paldiski } & \multicolumn{2}{|c|}{$\begin{array}{l}\text { Via Karlshamn- } \\
\text { Klaipeda }\end{array}$} \\
\hline 3.1. Dieppe-Tallinn & $3.2 \%$ & $4.5 \%$ & - & - & - & - \\
\hline 3.2. Dieppe-Kaunas & $3.3 \%$ & $4.6 \%$ & - & - & - & - \\
\hline 3.3. Antwerpen-Tallinn & $4.1 \%$ & $5.4 \%$ & - & - & - & - \\
\hline 3.4. Antwerpen-Kaunas & $4.3 \%$ & $5.5 \%$ & - & - & - & - \\
\hline 3.5. Amsterdam-Tallinn & $4.1 \%$ & $5.4 \%$ & - & - & - & - \\
\hline 3.6. Amsterdam-Kaunas & $4.2 \%$ & $5.5 \%$ & - & - & - & - \\
\hline 3.7. Hamburg-Tallinn & $7.1 \%$ & $7.9 \%$ & - & - & - & - \\
\hline 3.8. Hamburg-Kaunas & $7.3 \%$ & $8.1 \%$ & - & - & - & - \\
\hline 3.9. Esbjerg-Tallinn & $5.1 \%$ & $6.3 \%$ & $1.3 \%$ & $2.0 \%$ & - & - \\
\hline 3.10. Esbjerg-Kaunas & $5.3 \%$ & $6.5 \%$ & - & - & $2.4 \%$ & $3.5 \%$ \\
\hline West Europe-Scandinavia & \multicolumn{2}{|c|}{ Via Ghent-Göteborg } & \multicolumn{2}{|c|}{ Via Travemünde-Trelleborg } & \multicolumn{2}{|c|}{ Via Putgarten-Rödby } \\
\hline 4.1. Rotterdam-Oslo & $6.0 \%$ & $7.1 \%$ & $1.0 \%$ & $1.5 \%$ & $0.5 \%$ & $0.9 \%$ \\
\hline 4.2. Rotterdam-Stockholm & $4.9 \%$ & $6.2 \%$ & $0.9 \%$ & $1.5 \%$ & $0.5 \%$ & $0.9 \%$ \\
\hline
\end{tabular}


Table 5 Impact of the use of MGO (0.1\%) instead of HFO (1.5\%) on the total price per routing alternative - price increase in percent for transport between origin and destination (truck+shortsea) in May 2020 (low fuel prices)

\begin{tabular}{|c|c|c|c|c|c|c|}
\hline & \multicolumn{2}{|c|}{$\begin{array}{l}\text { Alternative } 2 \\
\text { (shortsea+truck) }\end{array}$} & \multicolumn{2}{|c|}{$\begin{array}{l}\text { Alternative } 3 \text { (shortsea+ } \\
\text { truck) }\end{array}$} & \multicolumn{2}{|c|}{$\begin{array}{l}\text { Alternative } 4 \text { (shortsea+ } \\
\text { truck) }\end{array}$} \\
\hline & roro $\min$ & roro $\max$ & roro $\mathrm{min}$ & roro $\max$ & roro $\mathrm{min}$ & roro $\max$ \\
\hline Germany/Denmark to Sweden & \multicolumn{2}{|c|}{$\begin{array}{l}\text { Via Travemünde- } \\
\text { Trelleborg }\end{array}$} & \multicolumn{2}{|c|}{$\begin{array}{l}\text { Via Putgarten-Rödby and } \\
\text { Oresund }\end{array}$} & \multicolumn{2}{|c|}{$\begin{array}{l}\text { Via P-R and Helsingör- } \\
\text { Helsingborg }\end{array}$} \\
\hline 1.1. Dortmund-Göteborg & $0.5 \%$ & $0.7 \%$ & $0.2 \%$ & $0.4 \%$ & $0.3 \%$ & $0.5 \%$ \\
\hline 1.2. Dortmund-Stockholm & $0.3 \%$ & $0.5 \%$ & $0.2 \%$ & $0.3 \%$ & $0.2 \%$ & $0.4 \%$ \\
\hline English Channel & \multicolumn{2}{|c|}{ Via Calais-Dover } & \multicolumn{2}{|c|}{ Via Rotterdam-Harwich } & \multicolumn{2}{|c|}{ Via Rotterdam-Hull } \\
\hline 2.1. Rotterdam-Tilbury & $0.8 \%$ & $1.1 \%$ & $1.1 \%$ & $1.4 \%$ & - & - \\
\hline 2.2. Rotterdam-London & $0.8 \%$ & $1.1 \%$ & $1.0 \%$ & $1.3 \%$ & - & - \\
\hline 2.3. Rotterdam-Portsmouth & $0.7 \%$ & $1.0 \%$ & $0.9 \%$ & $1.2 \%$ & - & - \\
\hline 2.4. Düsseldorf-Tilbury & $0.7 \%$ & $1.0 \%$ & $0.8 \%$ & $1.1 \%$ & - & - \\
\hline 2.5. Düsseldorf-London & $0.7 \%$ & $1.0 \%$ & $0.8 \%$ & $1.1 \%$ & - & - \\
\hline 2.6. Düsseldorf-Portsmouth & $0.6 \%$ & $0.9 \%$ & $0.6 \%$ & $0.9 \%$ & - & - \\
\hline 2.7. Brussels-Tilbury & $1.0 \%$ & $1.3 \%$ & $0.9 \%$ & $1.2 \%$ & - & - \\
\hline 2.8. Brussels-London $1.1 \%$ & $1.0 \%$ & $1.3 \%$ & $0.9 \%$ & $1.2 \%$ & - & - \\
\hline 2.9. Brussels-Portsmouth & $0.8 \%$ & $1.1 \%$ & $0.7 \%$ & $1.0 \%$ & - & - \\
\hline 2.10. Dortmund-Tilbury & $0.7 \%$ & $0.9 \%$ & $0.8 \%$ & $1.1 \%$ & - & - \\
\hline 2.11. Dortmund-London & $0.6 \%$ & $0.9 \%$ & $0.8 \%$ & $1.0 \%$ & - & - \\
\hline 2.12. Dortmund-Portsmouth & $0.6 \%$ & $0.8 \%$ & $0.6 \%$ & $0.8 \%$ & - & - \\
\hline 2.13. Rotterdam-Manchester & $0.5 \%$ & $0.7 \%$ & $0.7 \%$ & $1.0 \%$ & $1.1 \%$ & $1.4 \%$ \\
\hline 2.14. Düsseldorf-Manchester & $0.5 \%$ & $0.7 \%$ & $0.5 \%$ & $0.7 \%$ & $0.9 \%$ & $1.2 \%$ \\
\hline 2.15. Brussels-Manchester & $0.6 \%$ & $0.8 \%$ & $0.6 \%$ & $0.8 \%$ & $1.0 \%$ & $1.3 \%$ \\
\hline 2.16. Dortmund-Manchester & $0.4 \%$ & $0.6 \%$ & $0.5 \%$ & $0.7 \%$ & $0.9 \%$ & $1.2 \%$ \\
\hline West Europe-Baltic States & \multicolumn{2}{|c|}{ Via Lübeck-Riga } & \multicolumn{2}{|c|}{ Via Kappelskär-Paldiski } & \multicolumn{2}{|c|}{ Via Karlshamn-Klaipeda } \\
\hline 3.1. Dieppe-Tallinn & $1.1 \%$ & $1.4 \%$ & - & - & - & - \\
\hline 3.2. Dieppe-Kaunas & $1.1 \%$ & $1.4 \%$ & - & - & - & - \\
\hline 3.3. Antwerpen-Tallinn & $1.4 \%$ & $1.7 \%$ & - & - & - & - \\
\hline 3.4. Antwerpen-Kaunas & $1.4 \%$ & $1.7 \%$ & - & - & - & - \\
\hline 3.5. Amsterdam-Tallinn & $1.4 \%$ & $1.6 \%$ & - & - & - & - \\
\hline 3.6. Amsterdam-Kaunas & $1.4 \%$ & $1.7 \%$ & - & - & - & - \\
\hline 3.7. Hamburg-Tallinn & $2.4 \%$ & $2.5 \%$ & - & - & - & - \\
\hline 3.8. Hamburg-Kaunas & $2.5 \%$ & $2.5 \%$ & - & - & - & - \\
\hline 3.9. Esbjerg-Tallinn & $1.7 \%$ & $1.9 \%$ & $0.4 \%$ & $0.6 \%$ & - & - \\
\hline 3.10. Esbjerg-Kaunas & $1.8 \%$ & $2.0 \%$ & - & - & $0.8 \%$ & $1.0 \%$ \\
\hline West Europe-Scandinavia & \multicolumn{2}{|c|}{ Via Ghent-Göteborg } & \multicolumn{2}{|c|}{$\begin{array}{l}\text { Via Travemünde- } \\
\text { Trelleborg }\end{array}$} & \multicolumn{2}{|c|}{ Via Putgarten-Rödby } \\
\hline 4.1. Rotterdam-Oslo & $2.0 \%$ & $2.2 \%$ & $0.3 \%$ & $0.5 \%$ & $0.2 \%$ & $0.3 \%$ \\
\hline 4.2. Rotterdam-Stockholm & $1.7 \%$ & $1.9 \%$ & $0.3 \%$ & $0.5 \%$ & $0.2 \%$ & $0.3 \%$ \\
\hline
\end{tabular}


Table 6 Average route cost difference in percent with 'truck only' option (*)_October 2018 (left) and May 2020 (right)

\begin{tabular}{|c|c|c|c|c|c|c|c|c|c|c|c|c|c|}
\hline \multirow[b]{2}{*}{ October 2018} & \multicolumn{2}{|c|}{ Alternat. 2} & \multicolumn{2}{|c|}{ Alternat. 3} & \multicolumn{2}{|c|}{ Alternat. 4} & \multirow[b]{2}{*}{ May 2020} & \multicolumn{2}{|c|}{ Alternat. 2} & \multicolumn{2}{|c|}{ Alternat. 3} & \multicolumn{2}{|c|}{ Alternat. 4} \\
\hline & HFO & MGO & HFO & MGO & HFO & MGO & & HFO & MGO & HFO & MGO & HFO & MGO \\
\hline Germany/Denmark to Sweden & \multicolumn{2}{|c|}{ Travemünde-Trelleborg } & \multicolumn{2}{|c|}{ Putgarten-Rïdby } & \multicolumn{2}{|c|}{ P-R+ Hels. Hels. } & Germany/Denmark to Sweden & \multicolumn{2}{|c|}{ Travemünde-Treleborg } & \multicolumn{2}{|c|}{ Putgarten-Rōdby } & \multicolumn{2}{|c|}{ P-R+ Hels. -Hels. } \\
\hline 1.1. Dortmund - Göteborg & 29.4 & 28.1 & -5.2 & -6.1 & -0.6 & -1.9 & 1.1. Dortmund - Göteborg & 30.6 & 30.2 & -4.2 & -4.5 & 0.8 & 0.4 \\
\hline 1.2. Dortmund - Stockholm & 24.0 & 23.0 & -2.6 & -3.3 & 1.0 & 0.0 & 1.2. Dortmund - Stockholm & 25.0 & 24.7 & -1.8 & -2.1 & 2.0 & 1.7 \\
\hline AVERAGE & 26.7 & 25.5 & -3.9 & -4.7 & 0.2 & -0.9 & AVERAGE & 27.8 & 27.5 & -3.0 & -3.3 & 1.4 & 1.1 \\
\hline English Channel & \multicolumn{2}{|l|}{ Calas-Dover } & \multicolumn{2}{|c|}{ Rotterdam-Harwich } & \multicolumn{2}{|c|}{ Rotterdam-Hull } & English Channel & \multicolumn{2}{|c|}{ Calais-Dover } & \multicolumn{2}{|c|}{ Rotterdam-Harwich } & \multicolumn{2}{|c|}{ Rotterdam-Hull } \\
\hline 2.1. Rotterdam - Tilbury & -6.1 & -9.4 & 28.6 & 25.9 & & & 2.1. Rotterdam - Tilbury & -1.9 & -2.9 & 31.7 & 30.8 & & \\
\hline 2.2. Rotterdam - London & -5.8 & -9.0 & 28.2 & 25.6 & & & 2.2. Rotterdam - London & -1.8 & -2.8 & 31.3 & 30.4 & & \\
\hline 2.3. Rotterdam - Portsmouth & -5.0 & -7.8 & 30.0 & 27.7 & & & 2.3. Rotterdam - Portsmouth & -1.6 & -2.5 & 33.0 & 32.3 & & \\
\hline 2.4. Düsseldorf - Tilbury & -5.5 & -8.4 & 22.1 & 19.7 & & & 2.4. Düsseldorf - Tilbury & -2.0 & -2.9 & 24.8 & 24.1 & & \\
\hline 2.5. Düsseldorf - London & -5.2 & -8.0 & 22.1 & 19.8 & & & 2.5. Düsseldorf - London & -1.7 & -2.6 & 24.8 & 24.1 & & \\
\hline 2.6. Düsseldorf - Portsmouth & -4.6 & -7.0 & 13.0 & 11.0 & & & 2.6. Düsseldorf - Portsmouth & -1.6 & -2.3 & 15.5 & 14.9 & & \\
\hline 2.7. Brussels - Tilbury & -7.6 & -11.6 & 1.8 & -1.4 & & & 2.7. Brussels - Tilbury & -2.7 & -3.9 & 5.8 & 4.8 & & \\
\hline 2.8. Brussels - London & -7.3 & -11.1 & 1.1 & $\begin{array}{l}-1.4 \\
-2.2\end{array}$ & & & 2.8. Brussels - London & $\begin{array}{l}-2.1 \\
-2.4\end{array}$ & -3.6 & 5.3 & 4.4 & & \\
\hline 2.9. Brussels - Portsmouth & -6.3 & -9.6 & -4.0 & -6.8 & & & 2.9. Brussels - Portsmouth & -2.1 & -3.1 & -0.3 & -1.1 & & \\
\hline 2.10. Dortmund - Tilbury & -5.1 & -7.8 & 24.1 & 21.9 & & & 2.10. Dortmund - Tilbury & -1.7 & -2.5 & 26.7 & 26.0 & & \\
\hline 2.11. Dortmund - London & -4.7 & -7.3 & 24.1 & 21.9 & & & 2.11. Dortmund - London & -1.5 & -2.3 & 26.6 & 25.9 & & \\
\hline 2.12. Dortmund - Portsmouth & -4.2 & -6.5 & 15.2 & 13.3 & & & 2.12. Dortmund - Portsmouth & -1.3 & -2.1 & 17.6 & 17.0 & & \\
\hline 2.13. Rotterdam - Manchester & -3.7 & -5.7 & 38.7 & 37.1 & 48.2 & 46.1 & 2.13. Rotterdam - Manchester & -1.2 & -1.8 & 40.4 & 39.9 & 50.1 & 49.5 \\
\hline 2.14. Düsseldorf - Manchester & -3.3 & -5.2 & 21.1 & 19.6 & 42.4 & 40.5 & 2.14. Düsseldorf-Manchester & -1.1 & -1.6 & 22.9 & 22.4 & 44.2 & 43.6 \\
\hline 2.15. Brussels - Manchester & -4.2 & -6.5 & 11.4 & 9.5 & 36.2 & 33.7 & 2.15. Brussels - Manchester & -1.3 & -2.0 & 13.8 & 13.2 & 38.0 & 37.3 \\
\hline 2.16. Dortmund - Manchester & -3.2 & -5.0 & 22.4 & 20.9 & 42.9 & 41.0 & 2.16. Dortmund - Manchester & -1.0 & -1.6 & 24.1 & 23.6 & 44.5 & 44.0 \\
\hline AVERAGE & -5.1 & -7.9 & 18.8 & 16.5 & 42.4 & 40.4 & AVERAGE & -1.7 & -2.5 & 21.5 & 20.8 & 44.2 & 43.6 \\
\hline West Europe-Baltic States & \multicolumn{2}{|l|}{ Lübeck-Piga } & \multicolumn{2}{|c|}{ Kappelskär-Paldiski } & Karlshamn-1 & apeda & West Europe-Baltic States & Lübeck-Riga & & Kappelskär- & Idiski & Karlshamn-1 & aipeda \\
\hline 3.1. Dieppe - Tallinn & 20.5 & 17.3 & & & & & 3.1. Dieppe - Tallinn & 22.3 & 21.3 & & & & \\
\hline 3.2. Dieppe - Kaunas & -3.5 & -7.7 & & & & & 3.2. Dieppe - Kaunas & -1.1 & -2.4 & & & & \\
\hline 3.3. Antwerpen - Tallinn & 29.1 & 25.7 & & & & & 3.3. Antwerpen - Tallinn & 31.1 & 30.1 & & & & \\
\hline 3.4. Antwerpen - Kaunas & 7.7 & 3.1 & & & & & 3.4. Antwerpen - Kaunas & 10.4 & 9.0 & & & & \\
\hline 3.5. Amsterdam - Tallinn & 26.7 & 23.2 & & & & & 3.5. Amsterdam - Tallinn & 28.8 & 27.7 & & & & \\
\hline 3.6. Amsterdam - Kaunas & 3.6 & -1.2 & & & & & 3.6. Amsterdam - Kaunas & 6.4 & 4.9 & & & & \\
\hline 3.7. Hamburg - Tallinn & 44.5 & 40.3 & & & & & 3.7. Hamburg - Tallinn & $\begin{array}{l}0.4 \\
46.9\end{array}$ & 45.6 & & & & \\
\hline 3.8. Hamburg - Kaunas & 21.6 & 15.5 & & & & & 3.8. Hamburg - Kaunas & 25.1 & 23.3 & & & & \\
\hline 3.9. Esbjerg - Tallinn & 37.8 & 34.2 & 35.3 & 34.2 & & & 3.9. Esbjerg - Tallinn & 39.9 & 38.8 & 35.4 & 35.1 & & \\
\hline 3.10. Esbjerg - Kaunas & 18.2 & 13.2 & & & 31.9 & 29.9 & 3.10. Esbjerg - Kaunas & 21.0 & 19.5 & & & 32.4 & 31.8 \\
\hline AVERAGE & 20.6 & 16.4 & 35.3 & 34.2 & 31.9 & 29.9 & $\begin{array}{l}\text { AVERAGE } \\
\text { AVIl }\end{array}$ & 23.1 & 21.8 & 35.4 & 35.1 & 32.4 & 31.8 \\
\hline West Europe-Scandinavia & Ghent-Göteb & & Travemünde & relleborg & Putgarten-R & & West Europe-Scandinavia & Ghent-Gätet & & Travemünde & relleborg & Putgarten-F & \\
\hline 4.1. Rotterdam - Oslo & 38.6 & 34.5 & 19.9 & 18.9 & -5.6 & -6.4 & 4.1. Rotterdam - Oslo & 41.1 & 39.8 & 20.9 & 20.6 & -4.9 & -5.1 \\
\hline 4.2. Rotterdam - Stockholm & 30.1 & 26.2 & 19.5 & 18.5 & -5.3 & -6.0 & 4.2. Rotterdam - Stockholm & 32.6 & 31.4 & 20.4 & 20.1 & -4.6 & -4.8 \\
\hline AVERAGE & 34.3 & 30.3 & 19.7 & $\begin{array}{l}18.5 \\
18.7\end{array}$ & -5.4 & -6.2 & $\begin{array}{l}\text { AVERAGE } \\
\text { AVIOCKNOII }\end{array}$ & $\begin{array}{l}36.8 \\
36.8\end{array}$ & $\begin{array}{l}35.6 \\
35.6\end{array}$ & 20.7 & 20.4 & -4.7 & -5.0 \\
\hline
\end{tabular}

(*)The 'truck only' option in relation to traffic with the UK includes the use of the Channel Tunnel

links in Denmark (Great Belt and Oresund). However, the 'truck only' option shows a small cost advantage compared to alternative 3 which includes a short roro section. The total route cost of alternative 4 is almost the same as the 'truck only' option, with the cost advantage slightly tilting to the latter when using MGO.

The route competitiveness involving trade with the UK seems to be heavily affected by the relative fuel price levels. When fuel prices are high (October 2018), the cross channel shortsea business for manned truck/trailer combinations on the Calais-Dover link has a cost disadvantage compared to the Eurotunnel shuttle services. The use of MGO increases this route cost disadvantage compared to the 'truck only' option with 2.5 to $3.5 \%$ points. When fuel prices are low (May 2020), the cost difference between the Calais-Dover ferry services and the 'truck only' option is limited to only a few percent, with the use of low sulphur fuel not having a large impact. The RotterdamHarwich shortsea link shows the most competitive profile on all routes considered except for traffic flows to and from Manchester (i.e. cost advantage for route using the Rotterdam-Hull link). Except for some specific origin-destination pairs in relation to Brussels, the use of MGO does not seem to affect the cost advantage of the routes which use the Rotterdam-Harwich shortsea link.

The picture for the transport connections between Western Europe and the Baltic States is very mixed. The cost differential on routes that include the Lübeck-Riga shortsea connection is heavily affected by using low sulphur fuel, with in some cases a narrowing of the cost gap with the 'truck only' option of up to 5\% points. Despite these increased route costs due to the use of MGO, alternative 2 remains by far the most cost competitive option on most origin-destination relations. Only the routes from the Benelux and France to Kaunas show room for more intense competition between the 'truck only' option and the truck-roro combination using the Lübeck-Riga shortsea connection. In particular, shortsea services can lose some of their cost appeal to 
customers on the route Dieppe-Kaunas, potentially triggering a modal shift away from the Lübeck-Riga shortsea link.

At present, the shortsea connections between the Benelux/Western Germany and Scandinavia (Sweden and Norway in particular) face rather limited competition from road haulage. Despite a significant four percentage point drop in the relative cost advantage of alternative 2 based on October 2018 figures, the use of $\mathrm{MGO}$ is not expected to trigger a shift from long-distance roro services (such as Ghent-Göteburg) to medium/short distance maritime links. The use of low sulphur fuel is particularly having a negative impact on the cost position of the Putgarten-Rödby short-distance ferry option vis-à-vis the 'truck only' option.

In summary, the cost model output shows varying degrees of competition between the combined shortsea/truck alternatives and the 'truck only' alternative. The use of low-sulphur marine fuels is having an impact on the cost differentials between the different routing alternatives. However, in only a few cases, they are expected to tilt the balance in the modal competition towards the 'truck only' option (e.g. Brussels-UK and Benelux/France to Kaunas). In most cases, the price advantage of one or more of the combined truck-shortsea alternatives remains large enough to withstand a shift to the 'truck only' option.

\subsection{Sensitivity analysis on vessel utilization}

The results presented so far are based on the actual average two-way vessel utilization degrees as obtained from a few shortsea operators. Fleet capacity management for roro/ropax operators is complex given the inflexible nature of vessel capacity in the short run due to fixed timetables. If the vessel utilization degree decreases, the ship operating and capital costs as well as other costs (such as port dues) should be borne by less occupied lane metres. An operator confronted with sustained low utilization levels can resort to (1) a reduction of the vessel capacity offered on the route (e.g. by idling or removing vessels from the service to reduce service frequency and by slowing down the vessels or by opting for vessels with a smaller unit capacity) and/or (2) an increase in the freight rate to absorb the additional cost per occupied lane metre. In this section, we present the cost model output in case the average utilization drops by a third compared to the actual situation. We therefore apply the following average vessel utilization degrees (ratio of occupied vs. total available lane metres): $27 \%$ for ultra-short routes $(<50 \mathrm{~km}), 37 \%$ for short routes $(50-125 \mathrm{~km}), 40 \%$ for medium long routes $(125-400 \mathrm{~km})$ and $50 \%$ for long routes $(>400 \mathrm{~km})$. We assume the operators aim for cost recovery. Thus, the cost per 17 lane metres will increase accordingly to cover total shortsea trip costs.

Table 7 presents the impact of lower vessel utilization on the average cost differences between the routing alternatives. As expected, poor utilization degrees have a significant negative impact on the cost competitiveness of routing alternatives involving long, but also shorter roro sections. For example, the 'truck only' option now becomes the undisputed cost leader on the Brussels-UK routes and the Benelux/France to Kaunas connections, particularly when MGO is used. For many 
Table 7 Average route cost difference in percent with 'truck only' option-October 2018 (left) and May 2020 (right) — vessel utilization levels one third lower than normal

\begin{tabular}{|c|c|c|c|c|c|c|c|c|c|c|c|c|c|}
\hline \multirow[b]{2}{*}{$\begin{array}{l}\text { October } 2018 \\
\text { Vessel capacity utilis ation } 1 / 3 \text { lower }\end{array}$} & \multicolumn{2}{|c|}{ Alternat. 2} & \multicolumn{2}{|c|}{ Alternat. 3} & \multicolumn{2}{|c|}{ Alternat. 4} & \multirow[b]{2}{*}{$\begin{array}{l}\text { May } 2020 \\
\text { Vessel capacity utilis ation } 1 / 3 \text { lower }\end{array}$} & \multicolumn{2}{|c|}{ Alternat. 2} & \multicolumn{2}{|c|}{ Alternat. 3} & \multicolumn{2}{|c|}{ Alternat. 4} \\
\hline & HFO & MGO & HFO & MGO & HFO & MGO & & HFO & MGO & HFO & MGO & HFO & MGO \\
\hline Germany/Denmark to Sweden & \multicolumn{2}{|c|}{ Travemünde-Trelleborg } & \multicolumn{2}{|c|}{ Putgarten-R̈̈dby } & \multicolumn{2}{|c|}{ 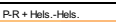 } & Germany/Denmark to Sweden & \multicolumn{2}{|c|}{ Travemünde-Trelleborg } & \multicolumn{2}{|c|}{ Putgarten-Pödby } & \multicolumn{2}{|c|}{ P-R + Hels. Hels. } \\
\hline 1.1. Dortmund - Göteborg & 24.9 & 23.0 & -8.5 & -9.9 & -4.9 & -6.7 & 1.1. Dortmund - Göteborg & 26.4 & 25.8 & -7.3 & -7.8 & -3.3 & -3.8 \\
\hline 1.2. Dortmund - Stockholm & 20.6 & 19.1 & -5.1 & -6.2 & -2.4 & -3.8 & 1.2. Dortmund - Stockholm & 21.7 & 21.3 & -4.3 & -4.6 & -1.1 & -1.5 \\
\hline AVERAGE & 22.7 & 21.1 & -6.8 & -8.0 & $\begin{array}{r}-3.7 \\
\end{array}$ & -5.2 & AVERAGE & 24.1 & 23.6 & -5.8 & $\begin{array}{r}-6.2 \\
\end{array}$ & -2.2 & -2.7 \\
\hline English Channel & \multicolumn{2}{|c|}{ Calais-Dover } & \multicolumn{2}{|c|}{ Rotterdam-Harwich } & \multicolumn{2}{|c|}{ Rotterdam-Hull } & English Channel & \multicolumn{2}{|c|}{ Calais-Dover } & \multicolumn{2}{|c|}{ Rotterdam-Harwich } & \multicolumn{2}{|c|}{ Rotterdam-Hull } \\
\hline 2.1. Rotterdam - Tilbury & -17.5 & -22.1 & 19.2 & 15.4 & & & 2.1. Rotterdam - Tilbury & -12.5 & -13.9 & 23.0 & 21.8 & & \\
\hline 2.2. Rotterdam - London & -16.7 & -21.2 & 19.2 & 15.6 & & & 2.2. Rotterdam - London & -12.0 & -13.3 & 22.9 & 21.8 & & \\
\hline 2.3. Rotterdam - Portsmouth & -14.6 & -18.4 & 22.2 & 19.0 & & & 2.3. Rotterdam - Portsmouth & -10.4 & -11.6 & 25.7 & 24.8 & & \\
\hline 2.4. Düsseldorf - Tilbury & -15.4 & -19.4 & 14.0 & 10.7 & & & 2.4. Düsseldorf - Tilbury & -11.1 & -12.3 & 17.3 & 16.3 & & \\
\hline 2.5. Düsseldorf - London & -14.7 & -18.5 & 14.3 & 11.2 & & & 2.5. Düsseldorf - London & -10.6 & -11.7 & 17.6 & 16.6 & & \\
\hline 2.6. Dusseldorf - Portsmouth & -13.0 & -16.4 & 6.1 & 3.3 & & & 2.6. Dussseldorf - Portsmouth & -9.4 & -10.4 & 9.1 & 8.2 & & \\
\hline 2.7. Brussels - Tilbury & -21.1 & -26.6 & -9.3 & -13.8 & & & 2.7. Brussels - Tilbury & -15.2 & -16.8 & -4.4 & -5.8 & & \\
\hline 2.8. Brussels - London & -20.5 & -25.9 & -9.9 & -14.3 & & & 2.8. Brussels - London & -14.7 & -16.3 & -4.7 & -6.1 & & \\
\hline 2.9. Brussels - Portsmouth & -17.7 & -22.4 & -13.5 & -17.3 & & & 2.9. Brussels - Portsmouth & -12.7 & -14.1 & -9.0 & -10.1 & & \\
\hline 2.10. Dortmund - Tilbury & -14.3 & -18.0 & 16.5 & 13.4 & & & 2.10. Dortmund - Tilbury & -10.3 & -11.4 & 19.6 & 18.7 & & \\
\hline 2.11. Dortmund - London & -13.6 & -17.3 & 16.8 & 13.8 & & & 2.11. Dortmund - London & -9.8 & -10.9 & & & & \\
\hline 2.12. Dortmund - Portsmouth & -12.1 & -15.4 & 8.7 & 6.1 & & & 2.12. Dortmund - Portsmouth & -8.7 & -9.7 & 11.5 & 10.7 & & \\
\hline 2.13. Rotterdam - Manchester & -10.6 & -13.4 & 33.1 & 30.8 & 41.0 & 38.1 & 2.13. Rotterdam - Manchester & -7.6 & -8.5 & 35.2 & 34.4 & 43.4 & 42.5 \\
\hline 2.14. Düsseldorf - Manchester & -9.6 & -12.2 & 15.9 & 13.8 & 35.9 & 33.2 & 2.14. Düsseldorf - Manchester & -6.9 & -7.7 & 18.1 & 17.4 & 38.1 & 37.2 \\
\hline 2.15. Brussels - Manchester & -12.0 & -15.2 & 5.0 & 2.4 & 28.0 & 24.6 & 2.15. Brussels - Manchester & -8.7 & -9.6 & 7.8 & 7.0 & 30.4 & 29.4 \\
\hline 2.16. Dortmund - Manchester & -9.2 & -11.7 & 17.4 & 15.4 & 36.6 & 34.0 & 2.16. Dortmund - Manchester & -6.7 & -7.4 & 19.4 & 18.8 & 38.7 & 37.9 \\
\hline $\begin{array}{l}\text { AVERAGE } \\
\text { AVE - }\end{array}$ & -14.5 & -18.4 & 11.0 & 7.8 & 35.4 & 32.5 & AVERAGE & $\begin{array}{l}-10.4 \\
-10.4\end{array}$ & $\begin{array}{l}-11.6 \\
-11.6\end{array}$ & 14.3 & 13.3 & 37.6 & 36.7 \\
\hline West Europe-Baltic States & \multicolumn{2}{|l|}{ Lübeck-figa } & \multicolumn{2}{|c|}{ Kappelskär-Paldiski } & Karlsham & ipeda & West Europe-Baltic States & Lübeck-Rgs & & Kappeskär & ibiski & Karlshamn-1 & apeda \\
\hline 3.1. Dieppe - Tallinn & 9.8 & 5.5 & & & & & 3.1. Dieppe - Tallinn & 12.2 & 10.9 & & & & \\
\hline 3.2. Dieppe - Kaunas & -17.7 & -23.5 & & & & & 3.2. Dieppe - Kaunas & -14.5 & -16.3 & & & & \\
\hline 3.3. Antwerpen - Tallinn & 17.4 & 12.6 & & & & & 3.3. Antwerpen - Tallinn & 20.1 & 18.6 & & & & \\
\hline 3.4. Antwerpen - Kaunas & -8.0 & -14.4 & & & & & 3.4. Antwerpen - Kaunas & -4.4 & -6.4 & & & & \\
\hline 3.5. Amsterdam - Tallinn & 14.7 & 9.7 & & & & & 3.5. Amsterdam - Tallinn & 17.4 & 15.9 & & & & \\
\hline 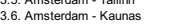 & -12.7 & $\begin{array}{l}-.19 \\
-19.4\end{array}$ & & & & & 3.6. Amsterdam - Kaunas & -9.0 & -11.0 & & & & \\
\hline 3.7. Hamburg - Tallinn & 30.2 & 24.3 & & & & & 3.7. Hamburg - Tallinn & 33.4 & 31.6 & & & & \\
\hline 3.8. Hamburg - Kaunas & 0.9 & -7.6 & & & & & 3.8. Hamburg - Kaunas & 5.6 & 3.0 & & & & \\
\hline 3.9. Esbjerg - Tallinn & 25.5 & 20.5 & 31.5 & 30.0 & & & 3.9. Esbjerg - Tallinn & 28.3 & 26.8 & 31.9 & 31.4 & & \\
\hline 3.10. Esbjerg - Kaunas & 1.4 & -5.5 & & & 25.0 & 22.2 & 3.10. Esbjerg - Kaunas & 5.2 & 3.1 & & & 25.9 & 25.1 \\
\hline AVERAGE & 6.1 & 0.2 & 31.5 & 30.0 & 25.0 & 22.2 & AVERAGE & 9.5 & 7.6 & 31.9 & 31.4 & 25.9 & 25.1 \\
\hline West Europe-Scandinavia & Ghent-Göteb & & Travemün & relleborg & Putgarten-1 & & West Europe-Scandinavia & Ghent-Göt & & Travemünd & relleborg & Putgarten-B $\mathrm{B}$ & \\
\hline 4.1. Rotterdam - Oslo & 24.7 & 19.0 & 16.5 & 15.1 & -8.2 & -9.2 & 4.1. Rotterdam - Oslo & 28.0 & ${ }^{9} 6.3$ & 17.6 & 17.2 & -7.3 & -7.6 \\
\hline 4.2. Rotterdam - Stockholm & 16.6 & 11.2 & 16.1 & 14.8 & -7.8 & -8.8 & 4.2. Rotterdam - Stockholm & 19.9 & 18.2 & 17.3 & 16.9 & -6.9 & -7.2 \\
\hline AVERAGE & 20.7 & 15.1 & 16.3 & 14.9 & -8.0 & -9.0 & AVERAGE & 24.0 & 22.2 & 17.5 & 17.0 & -7.1 & -7.4 \\
\hline
\end{tabular}

other routes, the cost lead of alternatives involving a shortsea connection declines to levels which no longer exclude competition of the 'truck only' option, see e.g. Dusseldorf-Portsmouth, Dortmund-Portsmouth and Brussels-Manchester when using the Rotterdam-Harwich shortsea service or Dieppe-Tallinn, HamburgKaunas and Esjberg-Kaunas when using the Lübeck-Riga roro connection. In these cases, the observed changes in cost differences following the use of MGO can trigger a modal shift from sea to road.

\section{Conclusions}

Roro/ropax operators in north Europe must comply with the strict low sulphur rules applicable in the SECAs. Existing academic studies and policy documents have shown various outcomes on the impact of low sulphur requirements on the cost competitiveness of shortsea services and the risks for triggering a 'modal back shift' from sea to road.

This study confirms that a long sea-leg length as part of total route length, high absolute fuel price levels and wide cost gaps between HFO and low sulphur fuels are the main factors increasing the risk for competition from land-based alternatives ('truck only' option) or routes with a shorter sea leg. Still, based on the situation in October 2018 (high fuel prices) and May 2020 (low fuel prices), we find that the use of low sulphur fuel has only a moderate impact on the cost competitiveness of shortsea routes. Only in a few cases (e.g. Brussels-UK and Benelux/France to Kaunas) do we see the cost balance in 
modal competition tilting towards the 'truck only' option. However, using the same set of origin-destination relations, Notteboom (2011) came to a much more dramatic conclusion, i.e. the transition to low sulphur fuel would lead to a particularly precarious cost competitiveness situation for cross channel shortsea business (manned truck/trailer combinations) and the transport connections between Western Europe and the Baltic States. A key reason for the more favourable outcomes in this study compared to Notteboom (2011) lies in the much smaller observed price gaps between HFO and low sulphur fuels. While Notteboom (2011) demonstrated that the price difference between MGO and IFO380 in the period 1990-2008 fluctuated between 30 and $250 \%$ with a longterm average of $93 \%$, low sulphur fuels in the past few years are only about 30 to $50 \%$ more expensive than IFO380. The smaller bunker price gap implies that the switch from IFO380 to low sulphur fuel did not lead to a hefty $31.1 \%$ increase in ship costs on average as was the case in July 2008, but only $8.9 \%$ in May 2020 and about $19.1 \%$ in October 2018. Thus, compared to the findings in Notteboom (2011), the compulsory transition to low sulphur emission solutions so far had far less significant impacts on the cost competitiveness of shortsea-dependent routing options vis-à-vis 'truck only' routing alternatives. The smaller differences in cost competitiveness compared to Notteboom (2011) are also partly explained by higher road charge costs for trucks following the introduction or increase of kilometre charges in various north European countries.

The sensitivity analysis in this paper demonstrates that the outcomes are not only dependent on different fuel cost situations and gaps. In particular, lower vessel utilization degrees can seriously affect the cost competitiveness of routing alternatives involving long and shorter roro sections and increase the risk of a modal back shift from sea to road. The latter outcome underlines the importance of an efficient and dynamic fleet management and deployment strategy by shortsea operators in view of securing the cost competitiveness of shortsea services and reduce fuel consumption levels.

This study contributes to extant literature dealing with the impact of low sulphur requirements in shipping on the competitiveness of shortsea services and modal competition. The updated outcomes confirm earlier findings in extant literature that modal back shift risks only exist for some very specific shipping categories and origin-destination routes. The presented study provides comprehensive and disaggregated results for no less than 30 routes using up-todate market data. Different fuel price levels are considered. Contrary to most earlier studies, the combination of many routes and several periods of observation allows to test the robustness of the outcomes under different spatial and temporal settings. The presented study solely focuses on the cost competitiveness of shortsea services from a route choice perspective. This implies the ecological impact in terms of overall emissions has not been modelled or assessed. The combination of economic and ecological analyses would provide a more thorough assessment of the full ramifications of existing low sulphur fuel requirements. 


\section{Appendix}

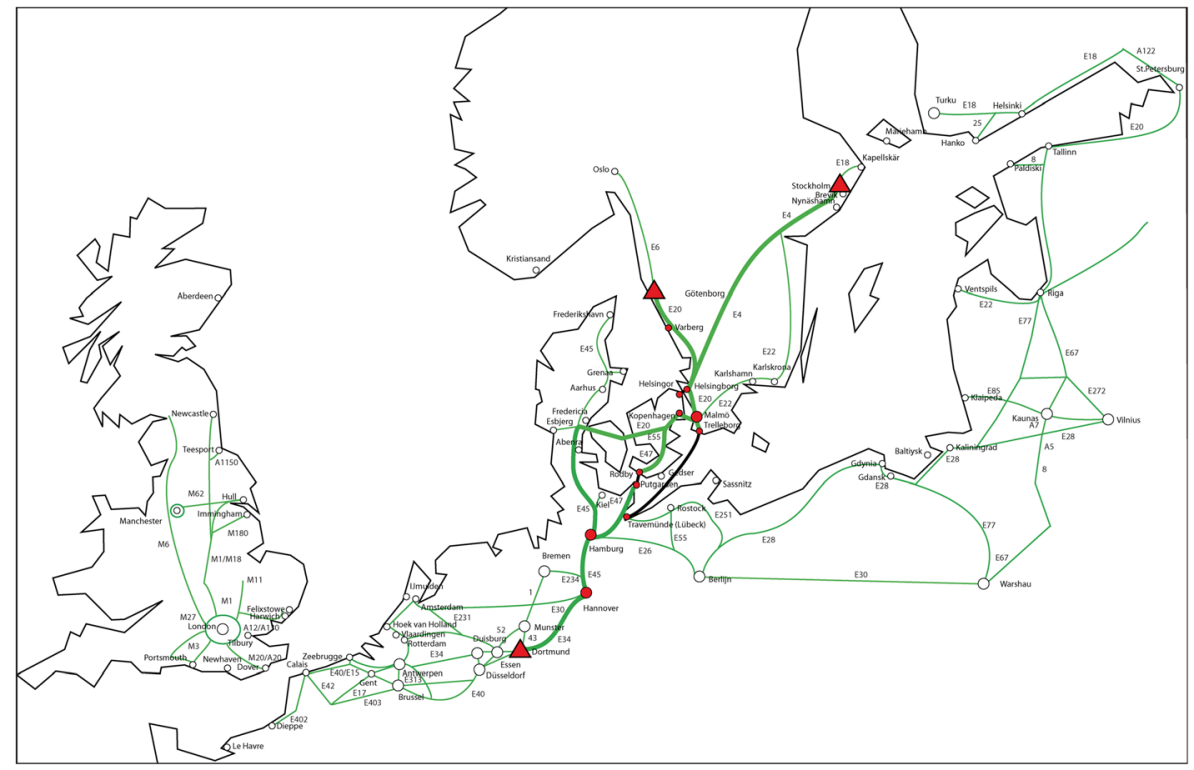

Fig. 9 Geographical representation of route group 1, Germany/Denmark to Sweden

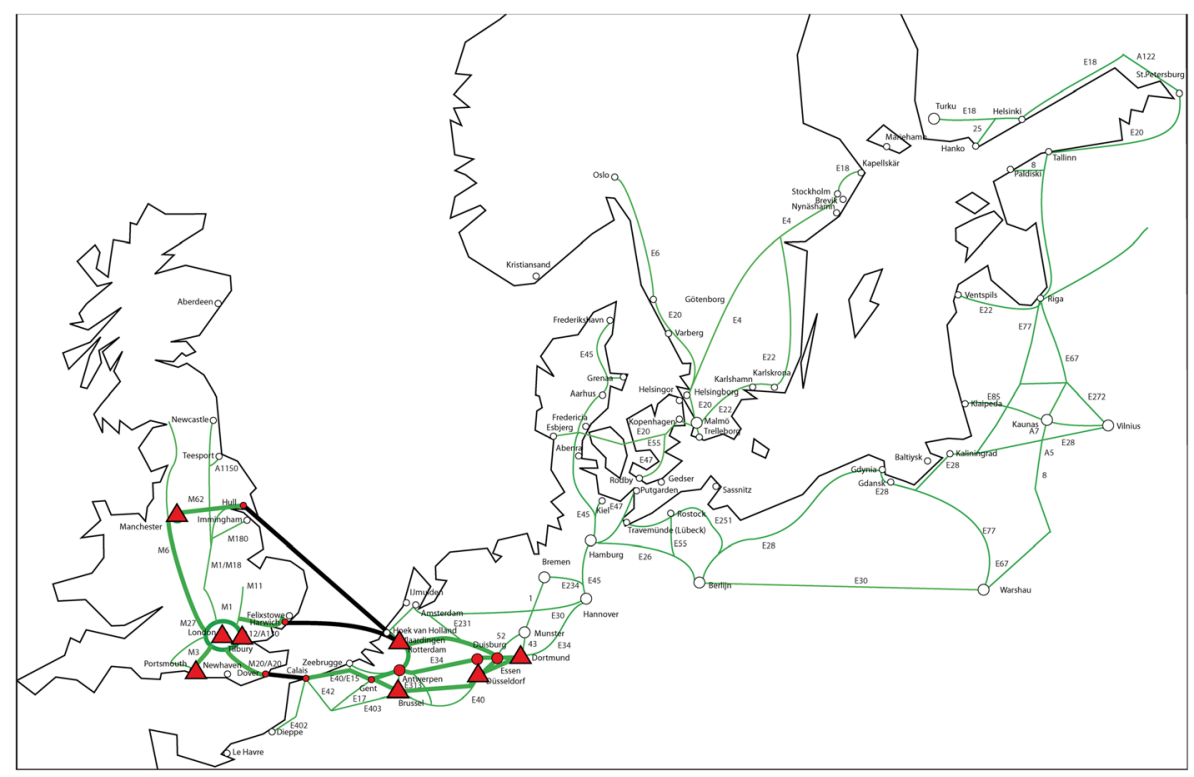

Fig. 10 Geographical representation of route group 2, the English Channel 


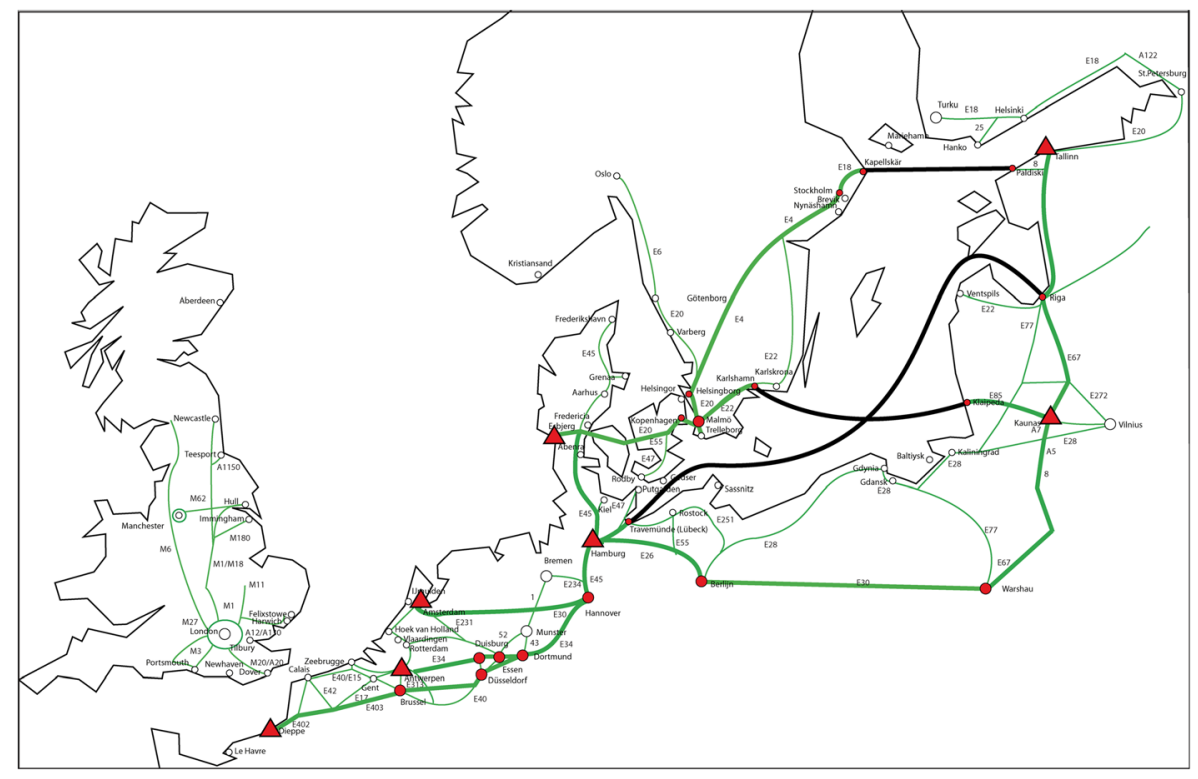

Fig. 11 Geographical representation of route group 3, west Europe to Baltic States

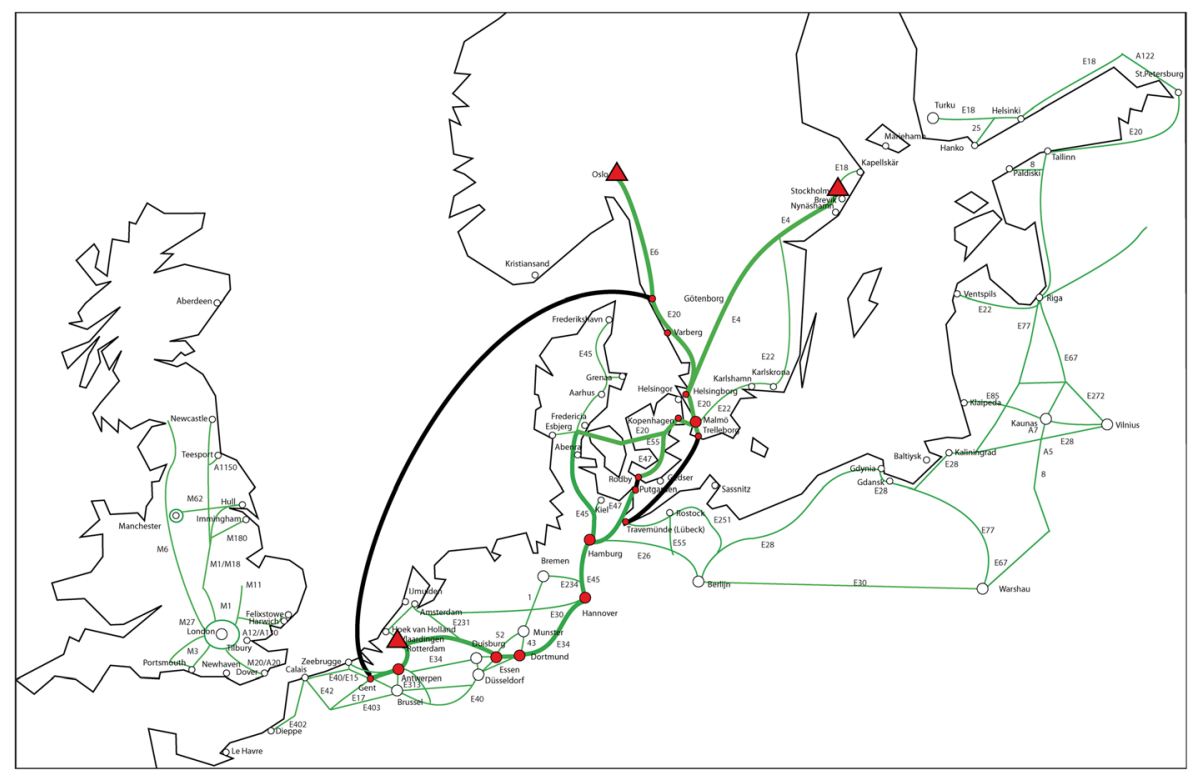

Fig. 12 Geographical representation of route group 4, west Europe to Scandinavia (Sweden/Norway) 
Table 8 Distribution of truck nationalities on different routes

\begin{tabular}{lllll}
\hline & $\begin{array}{l}\text { Germany/Denmark } \\
\text { to Sweden }\end{array}$ & English Channel & $\begin{array}{l}\text { West Europe-Baltic } \\
\text { States }\end{array}$ & $\begin{array}{c}\text { West Europe- } \\
\text { Scandinavia }\end{array}$ \\
\hline $\begin{array}{l}\text { Benelux/France/Western } \\
\quad \text { Germany }\end{array}$ & $75 \%$ & $50 \%$ & $20 \%$ & $70 \%$ \\
UK & $0 \%$ & $40 \%$ & $0 \%$ & $0 \%$ \\
Eastern Germany/Poland & $20 \%$ & $5 \%$ & $25 \%$ & $15 \%$ \\
Baltic States/Russia & $5 \%$ & $5 \%$ & $55 \%$ & $15 \%$ \\
\hline
\end{tabular}

Source: based on market information

\section{References}

ACEA (2019) Vehicles in use Europe 2019, European Automobile Manufacturers' Association (ACEA), Brussels

Delhaye E, Breemersch T, Vanherle K, Kehoe J, Liddane M, Riordan K (2010) The competitiveness of European short sea freight shipping compared with road and rail transport. In: Final report of the COMPASS project. Transport \& Mobility Leuven and Nautical Enterprise, Leuven and Cork

European Commission, (2013) Integrating maritime transport emissions in the EU's greenhouse gas reduction policies, available online

European Commission (2015) Analysis of recent trends in EU shipping and analysis and policy support to improve the competitiveness of short sea shipping in the EU. European Commission - DG Move, Brussels

Holmgren J, Nikopoulou Z, Ramstedt L, Woxenius J (2014) Modelling modal choice effects of regulation on low-sulphur marine fuels in Northern Europe. Transp Res D 28:62-73

IMO (2008) Revised MARPOL Annex VI: regulations for the prevention of air pollution from ships and NOx technical code. IMO Marine Environmental Protection Committee (MEPC), London

Industrierna S (2009) Information paper - consequences for the pulp and paper industry due to new sulphur regulations for ships. Swedish forest Industries Federation, Stockholm

Lemper B, Hader A, Hübscher A, Maatsch S, Tasto M (2009) Reducing the sulphur content of shipping fuels further to $0.1 \%$ in the North Sea and Baltic Sea in 2015: consequences for shipping in this shipping area. Final report. Institut für Seeverkehrswirtschaft und Logistik. Bremen

Morales-Fusco P, Saurí S, Lago A (2012) Potential freight distribution improvements using motorways of the sea. J Transp Geogr 24:1-11

Morales-Fusco P, Grau M, Saurí S (2018) Effects of RoPax shipping line strategies on freight price and transporter's choice. Policy implications for promoting MoS. Transp Policy 67:67-76

Notteboom T (2011) The impact of low sulphur fuel requirements in shipping on the competitiveness of roro shipping in Northern Europe. WMU J Marit Aff 10(1):63-95

Notteboom T, Vernimmen B (2009) The effect of high fuel costs on liner service configuration in container shipping. J Transp Geogr 17:325-337

Odgaard T, Frank C, Henriques M, Bøge M (2013) The impact on short sea shipping and the risk of modal shift from the establishment of an NOx emission control area, North Sea Consultation Group

Panagakos GP, Stamatopoulou EV, Psaraftis HN (2014) The possible designation of the Mediterranean Sea as a SECA: a case study. Transp Res D 28:74-90

Skema (2010) Impact study of the future requirements of Annex VI of the MARPOL Convention on Short Sea Shipping. Directorate-General for Energy and Transport, European Commission, Brussels

Wang J, Rakha HA (2017) Fuel consumption model for heavy duty diesel trucks: model development and testing. Transp Res D 55:127-141

Zis T, Psaraftis HN (2017) The implications of the new sulphur limits on the European Ro-Ro sector. Transp Res D 52:185-201

Zis T, Psaraftis HN (2018a) Operational measures to mitigate and reverse the potential modal shifts due to environmental legislation. Marit Policy Manag:1-16 
Zis T, Psaraftis HN (2018b) Key performance indicators to assess and reverse the negative impacts of SECAs policies for Ro-Ro shipping. FME Trans 46(3):347-354

Zis T, Angeloudis P, Bell MG, Psaraftis HN (2016) Payback period for emissions abatement alternatives: role of regulation and fuel prices. Transp Res Rec 2549:37-44

Publisher's note Springer Nature remains neutral with regard to jurisdictional claims in published maps and institutional affiliations.

\section{Affiliations}

\section{Theo Notteboom ${ }^{1,2,3}$}

1 Maritime Institute, Faculty of Law and Criminology, Ghent University, Ghent, Belgium

2 Faculty of Business and Economics, University of Antwerp, Antwerp, Belgium

3 Antwerp Maritime Academy, Antwerp, Belgium 